\title{
Evolutionäärinen tulkinta sektoritutkimuksen rakenteellisesta kehittämisestä ympäristö- ja luonnonvara- alalla
}

\author{
Jouko Inkeröinen
}

\begin{abstract}
The evolutionary approach to the long-term change in Finnish public research system

The article examines long-term structural change in Finland's public research institutes system within the framework of evolutionary organization theory, focusing on evolutionary features, selection environment and key mechanisms. Empirical data is gathered by thematic interviews.

Observation is that the mission to support evolutionary over revolutionary change has been gradually accomplished but opposing forces in selection environment have complicated the process. The aim to promote horizontal cooperation between sectorial institutes has formed new collaborative variants to system, but these have not been able to compete with institute fusion strategy.
\end{abstract}

Keywords: public research system, evolutionary organization theory, long-term structural change, Finland.

\section{JOHDANTO}

Yhteiskunnan toimintaa tukevan ja sille tiedollista pohjaa luovan sektoritutkimusjärjestelmän rakenteellinen kehittäminen on ollut yksi valtionhallinnon kehittämistavoitteista jo useita vuosikymmeniä. Kehittämistoiminta alkoi 1990luvun alusta jatkuen edelleen. Kehittäminen on ollut osa tutkimus- ja innovaatiopolitiikkaa, jossa heijastuvat myös yleiset julkishallinnon kehittämissuunnat (Virtanen 2016).

Sektoritutkimuksella tarkoitetaan yhteiskuntapolitiikkaa sekä yhteiskunnan palveluja ja toimintoja tukevaa tutkimusta (Valtioneuvoston kanslia 2012,28). Se on hallinnonalan politiikkojen suunnittelua, kehittämistä ja arviointia tukevaa, ministeriön tai sen alaisen viraston rahoittamaa tutkimusta valtion tutkimuslaitoksissa, yliopistoissa tai muissa tutkimusyksiköissä. Suomessa ministeriöt ovat keskeisessä roolissa sektoritutkimuksen kehittämisessä ja hyödyntämisessä. Ministeriöt tilaavat ja rahoittavat sektoritutkimusta, tulosohjaavat hallinnonalansa tutkimuslaitoksia ja hyödyntävät tutkimustuloksia (Karjalainen 2005). Valtion tutkimuslaitosten historia ulottuu 1800-luvulle ja 1900-luvun alkuun. Viimeisimmät tutkimuslaitokset on perustettu 1990-luvulla, kun keskusvirastoja muutettiin tutkimus- ja kehittämiskeskuksiksi. Tämän jälkeen uusia tutkimuslaitoksia on syntynyt viime vuosina tutkimuslaitosfuusioiden seurauksena.

Luonnonvara- ja ympäristöala muodostavat merkittävän kokonaisuuden sektoritutkimuskentässä. Erityisesti maa- ja metsätalousministeriön alalla on ollut useita tutkimuslaitoksia, jotka ovat muodostaneet merkittävän osan koko sektoritutkimusjärjestelmää. Ympäristötutkimus on puolestaan tyypillisesti muitakin hallinnonaloja kuin ympäristöministeriön hallinnonalaa läpileikkaava teema. Luonnonvara- ja ympäristöala yhdessä muodostavat kokonaisuuden, johon sektoritutkimuksen kehittämistarpeet ovat kohdentuneet voimakkaasti tarkastelujakson eri vaiheissa. Luonnonvara- ja ympäristöalan tutkimuslaitosrakenteen muuttuminen on esitetty kuviossa 1. Luonnonvara- ja ympäristöalan ministeriöiden välillä on myös tehty erilaisia yhteistyöratkaisuja tutkimusyhteistyön edistämiseksi. Nämä ovat perusteita, joiden takia juuri luonnonvara- ja ympäristöala on otettu tämän tutkimuksen tarkasteluun.

Tutkimuksen tavoitteena on kuvata miten ja miksi sektoritutkimuksen kehittämistavoitteet 


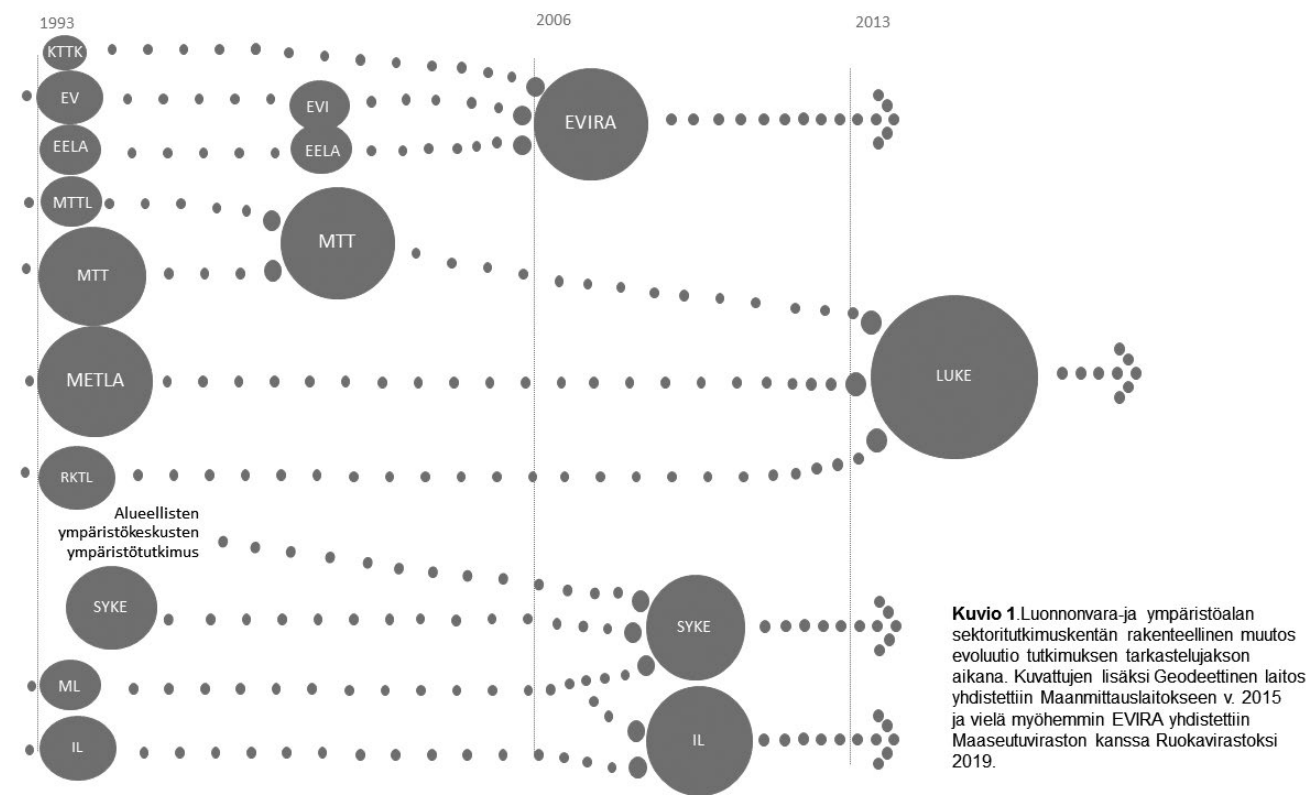

ja niiden toteuttamiseksi käytetyt keinot ovat muuttuneet viimeisen vajaan kolmenkymmenen vuoden aikana. Muutosta tulkitaan evolutiivisena muutosprosessina osana avointa tutkimus- ja innovaatiojärjestelmää. Tutkimuslaitokset käsitetään yhdeksi kokonaisuudeksi eli tutkimuslaitosjärjestelmäksi. Järjestelmän rakenteellinen uudistaminen on kestänyt arvioitua kauemmin, joten tutkimuksen tavoitteena onkin pyrkiä syventämään ymmärrystä kehityskulusta tuomalla esiin mukana olleiden näkökulmaa sekä löytää muutosprosessin kulun kannalta merkittävimpiä evolutiivisia mekanismeja. Erityisesti 2000-luvulla sektoritutkimuksen kehittämistoimista on tehty arviointeja, mutta tässä tutkimuksessa katsottua koko ajanjaksoa ei ole aiemmin tarkasteltu evolutionäärisellä lähestymistavalla, jossa ei arvioida vaan pyritään ymmärtämään itse muutosprosessia (Kuvio 2.). Luonnonvaraja ympäristöalaa on tässä tarkasteltu aihetta tarkentavana ja konkretisoivana tapauskohteena.

\section{TEORIAPERUSTA}

Organisaatiotutkimuksen evolutionäärinen lähestymistapa pyrkii selittämään tiettyjen organisaatiomuotojen olemassaoloa tietyssä ympäristössä (Aldrich 2007; Aldrich \& Ruef 2006, 35; Breslin 2008; Van den Ven \& Poole 1995, 514).
Peruskäsitteistö on peräisin biologian evoluutioteoriasta ja lähestymistavalla on pitkä historiansa eri tieteenaloilla ja se on edelleen leviämässä uusille tutkimusaloille (Nelson ym. 2018). Evoluutiokäsitettä käytettäessä sen määrittely ja viitekehys on tehtävä huolella (Lewis \& Steinmo 2012). Esimerkiksi politiikkatutkimuksessa evoluutiokäsitettä on käytetty laajalti ja vaihtelevin merkityksin kuvaamaan politiikan pitkän ajan muutosta tai politiikkaongelman ratkaisua (Cairney 2013). Mikäli evoluutiota sanana käytetään kuvaavana metaforana vähittäin tapahtuvalle muutosprosessille ilman rinnastusta biologiseen evoluutioon itse muutosteoriana, vältetään kritiikki siitä, että sosiaalisessa kontekstissa biologisen evoluution analogiat ovat harhaanjohtavia, koska luonnon valintaan rinnastettavaa taustavoimaa ei ole olemassa. Evolutionäärisellä näkökulmalla voi em. rajoituksesta huolimatta olla potentiaalia luonnollisten avoimien kompleksisten järjestelmien analysoinnissa (Kay \& Baines 2017). Universaalin darwinismin evoluutioteoreettiset koulukunnat pitävät evoluutiota jopa painovoimaan rinnastettavana universaalina ilmiönä, joka noudattaa tiettyä lainalaisuutta kontekstista riippumatta (Breslin 2008; Lewis \& Steinmo 2012; Abatecola 2014, 435).

Biologinen ja organisaatioteoreettinen evoluutionäkemys painottavat molemmat, että evo- 
III Viitekehys:

Sektoritutkimusjärjestelmän muutosten yleinen kuvaus ja eri ajanjaksot/sukupolvet

Valintaympäristön emergentti muutos sekä valintaympäristön kautta tehty tutkimuspoliittinen ohjaus/kehittäminen

II Evolutionääriset tekijät kehityskulun selittämisessä:

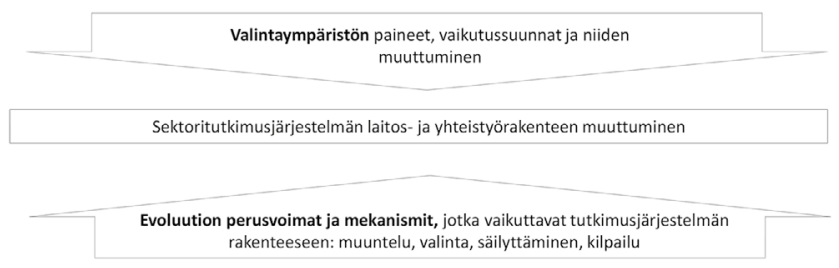

\section{(II)}

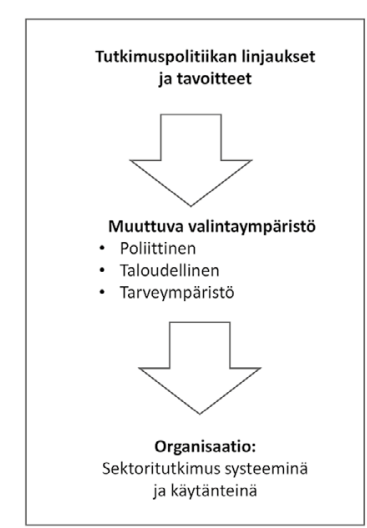

Kuvio 2. Tutkimuksen analyysikehikko. Tutkimuksen tavoitteena oli kuvata miten ja miksi sektoritutkimuksen kehittämistavoitteet ja niiden toteuttamiseksi käytetyt keinot ovat muuttuneet. Analyysi aloitettiin kuvaamalla sektoritutkimusjärjestelmässä tapahtuneet muutokset sekä valintaympäristön keskeiset tekijät ja niissä tapahtuneet muutokset. Tämän jälkeen tarkasteltiin sektoritutkimusjärjestelmän muutokseen vaikuttaneita paineita sekä etsittlin evolutionäärisen viitekehyksen tulkinnalla mekanismeja, jotka ovat rakennetta ja toiminnan käytänteitä muuttaneet tai säilyttäneet. Viitekehyksenä avoin organisaatioympäristö järjestelmä, jossa organisaatiomuutoksen ehtona on ympäristönkin muututtava.

luutioprosessi ei ole välttämättä kehittymistä positiiviseen suuntaan. Muutos voi olla positiivista, negatiivista tai neutraalia. (Aldrich 2007, 22; Aldrich \& Ruef 2006, 17; Kokko 2009, 22 23; Sotarauta 2004, 293-302). Evolutionääriselle tutkimusotteelle onkin tyypillistä pyrkimys ymmärtää itse muutosprosessia ilman arviointia. Evolutiivinen tarkastelu eroaa lähisukuisesta ekologisesta organisaatioteoriasta siten, että ekologinen tarkastelu painottaa enemmän organisaatioiden sisäisiä tekijöitä ja organisaatioiden ominaisuuksiin liittyviä tekijöitä (vrt. populaatioekologia esim. Baum \& Shipilov 2002, 57). Evoluutio muokkaa organisaatiot soveltuviksi ympäristöönsä, joten lähestymistavan peruselementtejä ovat ympäristön valintatekijät, jotka toimivat muutokseen pakottavina taustavoimina. Jotta organisaatiomuutosta tapahtuisi myös ympäristön tulee muuttua (Aldrich 2007, 56). Tarkasteltavien organisaatioiden osalta on tärkeää erottaa yksiköt, joihin evoluutio kohdistuu. Biologista perimää ja ilmiasua vastaaviksi yksiköiksi esitetään replicator ja interactor. Tarkasteltavat kohteet ovat joko olioita (entity) tai käytänteitä (practices) (Breslin 2008, Lewis \& Steinmo 2012). Ensin mainitussa oletuksena on, että ideat, tiedot ja kyvykkyys ovat sidoksissa yksilöihin, ryhmiin ja organisaatioihin. Käytännepohjaisessa lähestymistavassa paino- tus on prosessissa, joissa ideoita, osaamista ja kyvykkyyttä säädetään ja modifioidaan. Tässä tutkimuksessa painotutaan Breslinin $(2014,55)$ mallin mukaisesti käytännepohjaiseen (practices) lähestymistapaan ja voluntaristiseen valintanäkemykseen. Replikaattorina ovat tällöin rutiinit ja ilmiasuna erilaiset organisaatiota koskevat toimenpide- ja toimintamallikokonaisuudet.

Evolutiiviseen muutokseen ajavia perusvoimia ovat muuntelu, valinta, säilyttäminen ja kilpailu resursseista (Aldrich \& Ruef 2006,17; Jalonen 2006,18; Kuhmonen 2014,16; Sotarauta 2004, 293-295). Organisaatioissa muuntelu ilmenee joko organisaatioiden rutiinien, kompetenssin tai organisaatiomuotojen muuttumisena. Muuntelu voi olla aktiivista ja tietoista muutoksenhakua, ongelmanratkaisua tai sokeaa eli tiedostamatonta, vahingossa tapahtuvaa. Valinta on prosessi, joka valikoivasti suosii tai eliminoi tietyntyyppisiä organisaation rutiineihin tai kompetenssiin liittyviä ominaisuuksia. Valintaa voivat aiheuttaa joko ulkoiset vaikutteet tai organisaation sisältä lähtevät. Markkinavoimat, kilpailukykyyn liittyvät paineet ja institutionalisoituneet normistot ovat esimerkkejä ulkoisista valintapaineista. Organisaatioiden sisältä vaikuttavat esimerkiksi tarpeet pysyvyyteen ja homogeenisuuteen sekä sitkeästi organisaatiossa ylläpidettävät, mutta ei enää uudessa ympä- 


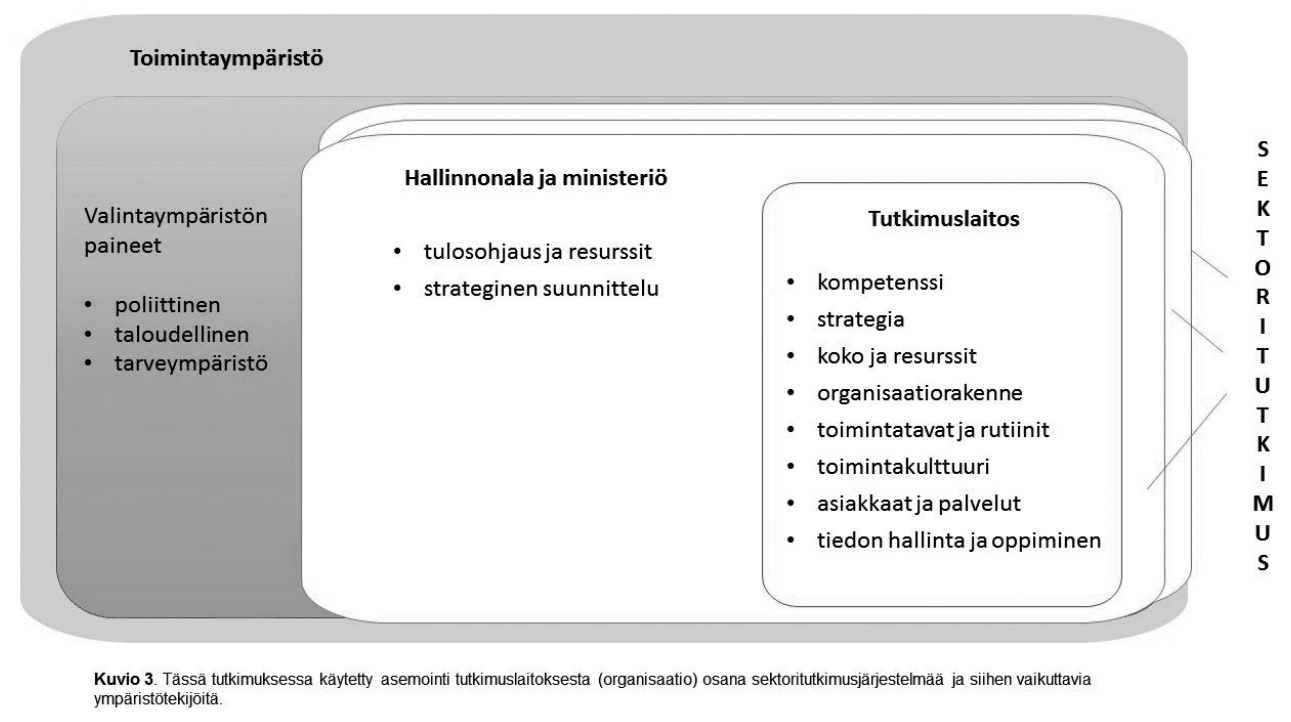

ristössä relevantit ominaispiirteet. Oppimis- ja osaamisvalmiudet sekä yritys-erehdys iteraatiot ja päätöksenteko voidaan nähdä osana valintamekanismeja. Säilyttäminen eli retentio tarkoittaa toimivien valittujen konseptien juurruttamista. Säilyttämiseen pyrkivät menettelytavat, rutiinit ja kollektiiviset normit mahdollistavat jatkuvuutta. Säilyttämistä edistävät myös koulutus, dokumentointi ja tiedonhallinta. Kilpailu tai kamppailu niukoista resursseista viittaa esimerkiksi pääomaan tai olemassaolon oikeutukseen. Valintapaineiden ja tehokkaiden sopeumien etsinnän taustalla on resurssien niukkuus organisaatioiden sisällä, välillä ja myös organisaatioryhmien välillä. Organisaatioissa esiintyy sisäistä kamppailua, koska sen jäsenet pyrkivät kohti omia henkilökohtaisia kannustimiaan ja organisaation tavoitteita. (Aldrich \& Ruef 2006, 17; Blute 2013; Lewis \& Steinmo 2012).

Valintaympäristö muodostaa käsitteellisen viitekehyksen, jonka avulla voidaan pyrkiä ymmärtämään niitä tekijöitä ja prosesseja, jotka yhtäl̈lä rajoittavat ja toisaalta mahdollistavat päätöksentekoa yhteiskunnan eri tasoilla. (Jalonen 2006; 123). Tässä tutkimuksessa tarkastellaan sektoritutkimusjärjestelmää, jonka muodostavat valtion tutkimuslaitokset (Kuvio 3.) yhtenä kokonaisuutena ja ulottuen osaksi niitä ohjaaviin ministeriöihin, suhteessa (toiminta)ympäristöönsä.

Tutkimuksen valintaympäristön määrittelyssä mukailtiin Kallion (1995) jakoa poliittiseen, taloudelliseen ja tarveympäristöön. Poliittinen valintaympäristö pitää tässä tapauksessa sisällään hallituspolitiikan sekä tutkimuspoliittiset linjaukset, joita kehittämisjakson aikana ovat olleet poliittiset tavoitteet julkisen hallinnon rakenteelliseksi uudistamiseksi, supistamiseksi, markkinamekanismin vahvistaminen sekä tutkimus-ja innovaatioympäristön kilpailukyvyn turvaaminen.

Tarveympäristö on poliittisen valintaympäristön johdannainen ja sisältää poliittisten päätösten implementointitarpeita. Tarveympäristöön vaikuttavina tekijöinä ovat kansalliset ja EUtason sektoripolitiikat. Nämä luovat jatkuvaa tiedon tarvetta ja ovat keskeinen peruste sektoritutkimusta tekeville tutkimuslaitoksille. Tämä tarveympäristö on tarkastelujakson aikana muuttunut ja laajentunut Europan Unioniin liittymisen myötä, koska EU-lainsäädännön tuominen kansalliseen järjestelmään on vaatinut huomattavasti tutkimuslaitosten panosta. Esimerkkinä ympäristöalalla vaikkapa EU:n vesipolitiikan puitedirektiivi. Lisäksi tästä tarveympäristöstä heijastuvat tutkimuslaitosten kansalliset seurantatehtävät ja viranomaistehtävät, jotka eivät ole varsinaista tutkimustoimintaa, mutta vaativat resursseja. Tällaisia ovat esimerkiksi riskien hallintaan, ympäristöntilan seurantaan ja turvallisuuteen liittyvät tehtävät.

Talousympäristö on puolestaan se kehys, jonka puitteissa toimintaa rahoitetaan tai joka 
antaa toiminnalle taloudellisia tavoitteita. Taloudellisen valintaympäristön muodostavat tutkimuslaitosten suora budjettirahoitus ja maksullinen palvelutoiminta, ministeriöiden sitomaton tutkimusmääräraha sekä kansainvälinen ja kansallisen tason vapaa tutkimusrahoitus.

\section{AINEISTO JA MENETELMÄT}

Lähtöaineistona tutkimuksessa ovat valtion tiede- ja teknologianeuvoston ja sittemmin valtion tutkimus- ja innovaationeuvoston selonteot (9 kpl v. 1987-2013). Nämä määräajoin tehdyt selonteot ovat olleet kansallisen tutkimus- ja innovaatiojärjestelmän keskeinen raportointiväline. Tätä tutkimusta varten selonteoista tarkasteltiin yleiset linjaukset ja sektoritutkimusta käsittelevät osiot. Näistä koottiin kehittämistavoitteet, ehdotetut toimenpiteet sekä muita sektoritutkimukseen suoraan tai välillisesti liittyviä seikkoja. Tarkentavina aineistoina käytettiin sektoritutkimuksen kehittämiseen liittyneiden selvitysmiesten raportteja (Huttunen 2004; Sektoritutkimustyöryhmä 2006; Rantanen 2008; Valtioneuvoston kanslia 2012), niitä seuranneita valtioneuvoston periaatepäätöksiä 2005, 2007 ja 2013 sekä sektoritutkimuksen neuvottelukunnan raportteja ja neuvottelukunnan toiminnasta tehtyä arviointia. Näiden avulla määritettiin tutkimusjärjestelmän ja sektoritutkimuslohkon rakenteellisen kehittämisen kehityskulkua eli merkittävimpiä etappeja, rakenteeseen tehtyjä muutoksia ja tavoiteasetannan muuttumista. Tutkimuksen laatuun ja laadun kehittämiseen liittyvät kysymykset rajattiin tästä tutkimuksesta pois, jotta tutkimusasetelma ei muodostuisi liian laajaksi. Horisontaalitutkimuksen tarkastelu rajattiin ympäristö- ja luonnonvara-alaan pois lukien TEM:n hallinnonalalla energiatutkimus ja VTT tutkimuslaitoksena. Niitä on TIN selonteoissa käsitelty osana tutkimusjärjestelmän teknologista tutkimusta ja VTT ei ole selkeästi hallinnonaloille sijoittuva sektoritutkimuslaitos vaan sen toimintakenttä on laajempi. Ympäristöja luonnonvara-alan laitosrakenteen muuttumisen kuvaus koottiin etupäässä TIN selonteoista.

Varsinainen aineiston keruu toteutettiin teemahaastatteluilla (Kuvio 4.). Lähtöaineiston perusteella muodostettiin haastattelujen runko ja pääteemat, jotka olivat sektoritutkimuksen kehittämisprosessin tausta ja tavoitteet, sekto- reita yhdistävän horisontaalitutkimuksen ja sitä tukevien yhteistyömuotojen ohjaus ja hallinta sekä tutkimusyhteistyön eri muodot ja niiden toimivuus eri ajanjaksoina. Lisäksi mukana oli avoimia kysymyksiä, joissa haastateltavat saivat kuvata tilanteen etenemistä omasta näkökulmastaan.

Pilottihaastattelut tehtiin ministeriöissä ( $2 \mathrm{kpl})$, valtion tutkimus- ja innovaationeuvostossa (1 haastattelu) sekä valtioneuvoston kansliassa (1 haastattelu). Pilottihaastattelujen perusteella tarkennettiin haastattelurunko ja saatiin ehdotuksia asiantuntijoista informanteiksi. Näistä nimistä ja tausta-aineistosta valittiin informantit ns. lumipallotekniikalla (SaaranenKauppinen \& Puusniekka 2006) niin, että mukaan otettiin sekä ministeriöiden (LVM, MMM, $\mathrm{YM}$,) tutkimuksesta vastaavia edustajia (informanttikoodit YL, 9 hlöä), että tutkimuspolitiikan kehityksessä pitkään olleita kehittäjiä ja vaikuttajia valtioneuvoston kansliassa, tutkimus-ja innovaationeuvostossa tai kehittämiseen liittyvissä työryhmissä (informanttikoodit PT, 10 hlöä). Tavoitteena oli saada mukaan asiantuntijoita, jotka edustavat eri laaja-alaisesti näkökulmia sektoritutkimuksen kehittämiseen (tutkimus-hallinto, sektorin sisältä - sektorin ulkoa) ja samalla ovat työssään kokeneet ajanjaksoa mahdollisimman pitkään. Informanteista 14 hlöä (73\%) oli ollut mukana aiheeseen liittyvissä tehtävissä koko tutkimuksen kattavan tarkastelujakson ajan. Kasvokkain haastattelut tehtiin vuoden 2013 aikana ja haastattelut nauhoitettiin. Kun kyseessä on pyrkimys ymmärtää ilmiötä, tämä katsottiin riittävän suureksi aineistoksi (Saaranen-Kauppinen \& Puusniekka 2006). Aineiston keruu ei ulotu vuoden 2013 jälkeisen ajan täysipainoiseen analysointiin. Tältä osin tietoa on täydennetty käyttämällä sekundäärisinä aineistoina uudistuksesta tehdyn arvioinnin julkaisuja (Haila ym. 2017, Haila ym. 2018).

Haastatteluaineistot anonymisoitiin, litteroitiin ja siirrettiin NVivo- ohjelmistoon, jossa luokittelun aluksi pääsanat olivat ohjaus, vaikuttavuus ja verkostot. Pääteemoiksi muodostuivat sittemmin toimintaympäristön ja tavoitteiden muuttuminen, tulosohjaus/tilaajaosaaminen sekä rakenteet (erilaiset yhteistyötavoitteet). Tässä vaiheessa aikajärjestys ja eri ajanjaksot nousivat tutkimuksen päärakenteeksi. Informanttien kokemuksiin pohjaten tarkennettiin ajanjaksojen 
Aineistotarkastelu työnimellä: Horisontaalisen tutkimusyhteistyön edistäminen

ympäristö- ja luonnonvara-alalla,

TIN selonteot, selvitysmiesraportit, valtioneuvoston periaatepäätökset
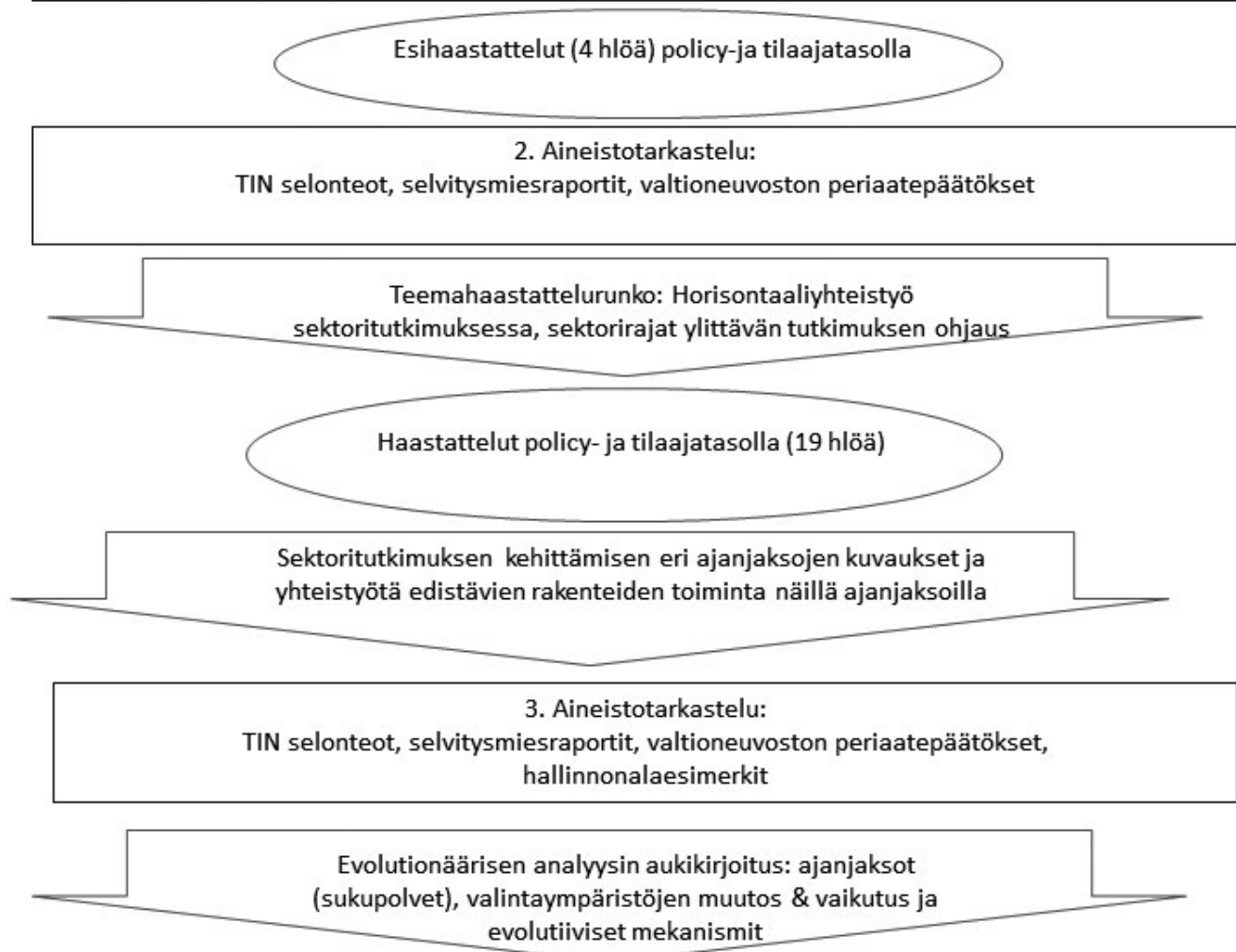

Kuvio 4. Tutkimusmenetelmän eri vaiheet.

kulkua sekä koottiin kuvaa tavoiteasetannasta, kehittämistoimien etenemisestä ja niiden onnistumisesta. Näin muodostuneiden vaihekuvien (ajanjaksot) toimintaa sekä itse sektoritutkimusrakenteessa, että sen toimintaympäristössä peilattiin tausta-aineistosta koottuihin tutkimuspoliittisiin tavoitteisiin ja esitettyihin rakenteellisen kehittämisen toimiin. Lisäksi etsittiin tekijöitä, jotka joko suosivat tai vastustivat muutosta (Kuvio 5.).

\section{Sektoritutkimuksen kehittämisen tutkimus- ja innovaatiopoliittiset ajanjaksot}

Tarkasteluajanjakso jäsennettiin kolmeen vaiheeseen: 1) yleismallin aikaan (YLEIS) alkaen Valtio tiede- ja tutkimusneuvoston linjauksesta vuodelta 1993, 2) sektoritutkimuksen neu- vottelukunnan aikaan (SETU) alkaen vuoden 2007 Valtioneuvoston periaatepäätöksestä sekä 3) tutkimuslaitos- ja -rahoitusjärjestelmän kokonaisuudistusvaiheeseen (TULA) alkaen Valtioneuvoston periaatepäätöksestä 2013 (Taulukko 1.). Seuraavassa kerrotaan näistä vaiheista tarkemmin:

Valtion tiede-ja teknologianeuvosto esitteli 1990-luvun alussa suomalaisen tiede- ja teknologiapolitiikan perustaksi sektoritutkimuksen yleismallin (Valtion tiede- ja teknologianeuvosto 1993). Sen mukaan monitasoisessa järjestelmässä valtiokonserni on laajin taso. Tämän alla toimii tutkimus- ja innovaatiojärjestelmä, jonka osana on puolestaan tutkimusjärjestelmä. Tutkimusjärjestelmän muodostavat kolme osiota: perustutkimuksellinen yliopistotutkimus, teknologinen tutkimus sekä kolmantena lohko- 
na sektoritutkimus, jota toteuttavat valtion tutkimuslaitokset etupäässä ministeriöiden rahoittamana. Yleismalli perustui siihen, että tutkimuslaitokset toimisivat avoimissa verkostoissa yhdessä muiden tutkimustiedon tuottajien ja hyödyntäjien sekä tutkimuksen rahoittajien kanssa (Huttunen 2004; Rantanen 2008). Yleismallin linjauksessa pidettiin tärkeänä, että tutkimuslaitoksia ja samalla koko sektoritutkimuksen kenttää kehitetään funktionaalisesti, toiminnallisista tarpeista lähtien. Tutkimuslaitoskenttä jaettiin kolmeen osaan sen mukaan, mikä on laitosten väljästi tulkittu tutkimuskohde: 1) luontoa tai luonnonvaroja koskevat tutkimuslaitokset, 2) ihmistä yksilönä ja toimintaympäristössään tutkivat laitokset ja 3) kulttuuria ja yhteiskuntaa tutkivat laitokset.

Valtioneuvosto antoi 2000-luvun alussa kaksi sektoritutkimusta koskevaa periaatepäätöstä (v. 2005 ja 2007). Molemmat pohjautuivat laajoihin selvityksiin ja selvitysmiestöihin (Huttunen 2004, Sektoritutkimustyöryhmä 2006). Sektoritutkimusta uudistettiin ottamalla käyttöön ministeriöiden yhteisen sektoritutkimuksen toimintamalli (Taulukko 1). Toimintaa ohjaamaan perustettiin sektoritutkimuksen neuvottelukunta. Toiminta pohjautui yhteiskunnan tutkimustarpeen arviointiin sekä ministeriöiden esittämien yhteisten tutkimustehtävien pohjalta laadittuihin tutkimusohjelmakokonaisuuksiin. Linjaus tukeutui hallinnonalakohtaiseen tulosohjausmenettelyyn, jota oli tarkoitus vahvistaa ja tukea neuvottelukunnan toimenpitein nimenomaan sektoreidenvälisen tutkimuksen kehittämiseksi. Tutkimuslaitosten kesken esitettiin muodostettavaksi yhteistyökonsortioita, joiden tehtävänä oli organisoida sektoreidenvälistä tutkimuksen tuottajayhteistyötä. Vuoden 2007 periaatepäätöksessä määriteltiin neljä tutkimuksen aihealuetta, joiden tutkimusta suunnitteli ja koordinoi neljä neuvottelukunnan jaostoa. Aihealueet olivat 1) alue- ja yhdyskuntarakenteet ja infrastruktuurit, 2) osaaminen, työ ja hyvinvointi, 3) kestävä kehitys ja 4) turvallisuus. Näin muodostettua tilaaja-tuottajamallia oli tarkoitus soveltaa sektoreidenvälisen tutkimuksen rahoituksessa ja sektoritutkimuksen neuvottelukunnan jaostojen tutkimusagendojen toimeenpanossa. Tilaaja-tuottajamalli tavoitteli askeleita kohti suurempia, hyvin resursoituja toiminnallisia kokonaisuuksia (Rantanen 2008).
Neuvottelukunnan toiminnan arvioinnissa (Harrinvirta 2010) todettiin, että tavoitteet olivat ristiriidassa neuvottelukunnan todelliseen toimintakykyyn verrattuna. Neuvottelukunnan toiminta lakkautettiin ja valtioneuvoston kanslian toimesta käynnistettiin uusi selvitys tutkimuslaitosjärjestelmän ja -rahoituksen kokonaisuudistukseksi (TULA ks. Taulukko 1.) (Valtioneuvoston kanslia 2012).

Valtioneuvoston periaatepäätös valtion tutkimuslaitosten ja tutkimusrahoituksen kokonaisuudistukseksi (2013) korostaa, että yhteiskuntapolitiikan valmistelun, päätöksenteon ja toimeenpanon tulisi perustua tutkittuun tietoon. TULA-uudistuksessa tutkimuslaitoksia yhdistettiin ja horisontaalitutkimusta kehitetään luomalla uudenlaisia rahoitusmalleja (Taulukko 1.). Strategisen tutkimuksen vahvistamiseksi tieteellisen tutkimuksen ja innovaatioiden rahoitusvälineiden rinnalle perustettiin kolmas kilpaillun rahoituksen pilari, strategisesti suunnatun tutkimuksen rahoitusväline. Lisäksi valtioneuvoston yhteiskunnallista päätöksentekoa tukevaa tutkimus- ja selvitystoimintaan kootaan rahoitusta valtion tutkimuslaitosten budjettirahoitteisista tutkimusmäärärahoista. Valtioneuvosto vahvistaa vuosittain päätöksentekoa tukevan selvitysja tutkimussuunnitelman. Sillä ohjataan selvitysja tutkimustoimintaa hallituksen valitsemille painopistealueille (Valtioneuvoston kanslia 2012). Vuonna 2018 TULA-uudistus arviointiin (Haila ym. 2018) ja siinä todettiin, että uudistus on onnistunut tavoitteessaan kohdentaa tutkimusrahoitusta vahvistamaan tutkimuksen relevanssia, kysyntälähtöisyyttä ja monitieteisyyttä. Toimijoiden välinen yhteistyö on monipuolistunut ja yhteisten tietotarpeiden tunnistaminen on kehittynyt ministeriöissä. Sen sijaan tiedon hyödyntämistä poliittisen päätöksenteon prosesseissa ei ole kehitetty samassa tahdissa.

\section{TULOKSET}

\section{Tutkimuspoliittinen valintaympäristö - kehittämistavoitteiden ja niiden toteuttamismallien kehityskulku}

Sektoritutkimuksen yleiset tutkimuspoliittiset kehittämistavoitteet ovat pysyneet samoina tarkastelun kaikkina ajanjaksoina (Taulukko 1.). Tutkimuslaitoskenttää on pyritty tasapainotta- 
Taulukko 1. Sektoritutkimuksen kehittämisjaksojen vertailu

\begin{tabular}{|c|c|c|c|}
\hline & YLEISMALLI 1993 & SETU-MALLI 2007 & TULA-MALLI 2013 \\
\hline \multirow[t]{2}{*}{$\begin{array}{l}\text { Kehittämisen } \\
\text { päätavoitteet }\end{array}$} & $\begin{array}{l}\text { Tutkimuslaitosten } \\
\text { kilpailukyvyn ja } \\
\text { yhteiskunnallisen relevanssin } \\
\text { varmistaminen, määrän } \\
\text { vähentäminen ja koon } \\
\text { kasvattaminen. }\end{array}$ & $\begin{array}{l}\text { Tutkimuslaitosten } \\
\text { kilpailukyvyn ja } \\
\text { yhteiskunnallisen } \\
\text { relevanssin varmistaminen, } \\
\text { määrän vähentäminen } \\
\text { ja koon kasvattaminen. } \\
\text { Horisontaalisen yhteistyön } \\
\text { kehittäminen. }\end{array}$ & $\begin{array}{l}\text { Tutkimuslaitosten } \\
\text { kilpailukyvyn ja } \\
\text { yhteiskunnallisen } \\
\text { relevanssin varmistaminen, } \\
\text { määrän vähentäminen } \\
\text { ja koon kasvattaminen. } \\
\text { Tiedon tehostettu vienti } \\
\text { päätöksentekoon. }\end{array}$ \\
\hline & $\begin{array}{l}\text { Eri alojen valtion } \\
\text { tutkimuslaitosten } \\
\text { koonti yhtenäiseksi } \\
\text { tutkimuslaitosjärjestelmäksi } \\
\text { ml. rahoitusmekanismit ja } \\
\text { yhteiset toimintaperiaatteet. }\end{array}$ & $\begin{array}{l}\text { Järjestelmän rakenteellinen } \\
\text { uudistaminen ja erityisesti } \\
\text { horisontaalisen tutkimuksen } \\
\text { edistäminen uusien } \\
\text { tutkimustarpeiden myötä. }\end{array}$ & $\begin{array}{l}\text { Järjestelmän } \\
\text { kokonaisuudistus ja uudet } \\
\text { rahoitusmekanismit. }\end{array}$ \\
\hline Pääsuunta & sektorinsisäinen & horisontaalinen & $\begin{array}{l}\text { sektorinsisäinen ja } \\
\text { horisontaalinen }\end{array}$ \\
\hline Rahoitusmalli & $\begin{array}{l}\text { Tutkimuslaitoksilta siirretään } \\
\text { rahaa ministeriöille ja } \\
\text { samalla sitomatonta lisätään } \\
\text { ministeriöihin. }\end{array}$ & $\begin{array}{l}\text { Erityinen ohjelmatyyppinen } \\
\text { sektoritutkimusrahoitus } \\
\text { setu-neuvottelukunnalle } \\
\text { kootaan pääosin } \\
\text { ministeriöiltä, } \\
\text { tutkimuslaitosten } \\
\text { omarahoituksesta } \\
\text { hankkeisiin ja niihin } \\
\text { osallistuvat myös muut } \\
\text { tutkimusrahoittajat. }\end{array}$ & $\begin{array}{l}\text { Tutkimuslaitoksilta ja } \\
\text {-rahoittajilta kootaan } \\
\text { yhteinen resurssi. } \\
\text { Lyhytaikaisiin (VN/TEAS) ja } \\
\text { pitkäaikaisiin kilpailtaviin } \\
\text { ohjelmatyyppisiin } \\
\text { rahoituskanaviin (SA/STN). }\end{array}$ \\
\hline Tilaajamalli & $\begin{array}{l}\text { Ministeriöiden tilaus, } \\
\text { tutkimuslaitosten } \\
\text { hallinnollista suhdetta } \\
\text { ministeriöön löyhennetään. }\end{array}$ & $\begin{array}{l}\text { Konsortiotilauspainotteinen } \\
\text { (ministeriöiden yhteinen } \\
+ \text { tutkimusrahoittajat) \& } \\
\text { ministeriöiden tulosohjaus. }\end{array}$ & $\begin{array}{l}\text { Valtioneuvosto-tason } \\
\text { ohjelma TEAS hankkeissa } \\
\text { ja Strategisen tutkimuksen } \\
\text { neuvosto Suomen } \\
\text { Akatemian yhteyteen. } \\
\text { Laitosten yhteenliittymillä } \\
\text { ministeriöiden yhteinen } \\
\text { tulosohjaus. }\end{array}$ \\
\hline $\begin{array}{l}\text { Tutkimuslaitos- } \\
\text { kentän } \\
\text { rakenteellinen } \\
\text { uudistaminen }\end{array}$ & $\begin{array}{l}\text { Itseohjautuvasti } \\
\text { laitosfuusioihin } \\
\text { markkinamekanismilla. }\end{array}$ & $\begin{array}{l}\text { Itseohjautuvasti } \\
\text { vaiheittain laitosfuusioihin } \\
\text { teemoittaisen yhteistyön } \\
\text { tiivistymisen kautta. }\end{array}$ & $\begin{array}{l}\text { Laitosfuusiot hallinnollisin } \\
\text { päätöksin ja asetuspohjaiset } \\
\text { yhteenliittymät. }\end{array}$ \\
\hline
\end{tabular}

maan kattamaan yhteiskuntapolitiikkaa aiempaa laajemmin. Tutkimuslaitosten kilpailukykyä tutkimuksen laadun ja relevanssin suhteen on haluttu varmistaa. Laitosten määrää on haluttu vähentää ja vastaavasti kokoa kasvattaa.

Ajanjakson aikana muutosta tapahtui hyödynnettävissä muutosmekanismeissa, rakenteellista muutosta tukevassa rahoitusmallissa sekä sektoritutkimuksen tilaajamallissa (Taulukko 1.).

Sektoritutkimuksen yleismallin päämääränä oli tutkimuslaitosten kehittyminen ja järjestymi- nen laaja-alaisiksi asiantuntijaorganisaatioiksi, jotka pystyvät palvelemaan useampaa kuin yhtä ministeriötä. Tavoitteena oli 4-5 suurta monitieteistä teemapohjaista tutkimuslaitosta, joihin (tai yliopistoihin) pienemmät tutkimuslaitokset sitten sulautuisivat. Suureen kerralliseen reformiin tutkimuslaitoskentässä ei pyritty. Sen sijaan pyrittiin saamaan aikaan kehitysprosesseja funktionaalisen yhteistyön pohjalta siten, että lähtökohtana ovat yhteiskunnan tutkimustarpeet. 
"Ajateltiin että saadaan se prosessi liikkeelle, kun muutetaan tätä järjestelmää tällä tavalla. Ei niin, että me tehdään semmosta revoluutiota, vaan me saadaan syntymään semmonen evoluutio. Ja me tuodaan tämmönen, sanotaan tietyn tyyppinen markkinamekanismi -ei markkinamekanismi kaupallisessa mielessä vaan tämmönen markkinamekanismi tämmösessä teoreettisessa mielessä järjestelmän sisään, jollonka se alkaa, syntyy niitä insentiivejä että järjestelmä alkaa itse kehittyä. " PT10

"Holkerin hallitus sillon rupes näkemään, et tää tutkimushomma on tärkeää, myös poliittisen päätöksentekoon, ja sitten kirjas tämmösiä periaatteita, [...] peruslinja näissä on se, että, näitten sektoritutkimuslaitosten tulee palvella koko valtioneuvostoa, ja tietysti koko yhteiskuntaakin, [...] Ja sitte tää kilpailuttaminen tuli vaan, niin ku muutenkin ni se on pikkuhiljaa tullu yhteiskuntaan sitten." YL3

Yleismallin markkinamekanismi ei kuitenkaan purrut halutussa muodossa. Laitosrakenne toki muuttui (Kuvio 1.), kun tutkimuslaitosfuusioita tehtiin hallinnonalojen sisäisenä kehittämisenä. Samaan aikaan tuotiin hallintoon tulosohjausjärjestelmä, jolloin ministeriöiden ja niiden tutkimuslaitosten suhde tuli entistä kiinteämmäksi. Evolutionäärisesti tulkittuna poliittinen valintaympäristö ei tukenut toivottua muutosta. Taloudellinen valintapainekaan ei ollut riittävä ja taistelua niukoista resursseista ei syntynyt. Tutkimuslaitokset sopeutuivat uuteen tulosohjauskäytäntöön, joka loi heille oman ekolokeronsa ministeriön sitomattoman määrärahoituksen hyödyntämisessä. Lisäksi kentälle alkoivat nousta ulkopuolisen rahoitukseen ja yhteisrahoitukseen perustuvat tutkimusohjelmat, jotka lisäsivät muuntelua yhteistyön edistämismuotoina vaikkakin pienemmässä mittakaavassa.

Sektoritutkimuksen neuvottelukunnalla pyrittiin nopeuttamaan rakenteellista kehittämistä ja edistämään poikkisektoraalista (jatkossa tekstissä horisontaalista) tutkimusta vieläkin selkeämmin yhteistyörakenteiden kautta. Tutkimuslaitosten verkostoitumisen oletettiin edistävän muutosta - luovan erilaisia sopeumia ja edelleen uusia organisaatiota etenkin taloudellisen valintaympäristön paineessa Katsottiin, että tuottajakentän tarkoituksenmukaisuuden arviointi ja tilaaja-tuottajakonsortiot lopulta johtaisivat myös laitosfuusioihin. Konsortiot kaavailtiin sekä tilaajapuolelle (ministeriöt, tutkimusrahoittajat) että tuottajapuolelle (tutkimuslaitokset, yliopistot, muut). SETU-neuvottelukunnan "verkostoitumismekanismin" tavoitteista yhteistyön tehostaminen ja etenkin toimivien tuottajakonsortioiden muodostaminen toteutuivat. Sektoritutkimuksen suuntaamisessa ja tuottajakentän tarkoituksenmukaisuuden parantamisessa ei edetty.

"No se ois musta ollu se sen neuvottelukunnan tärkein tehtävä. Sitä varten mä ajattelin että se olis olemassa [...] Ja sitten, nyt tutkimuksen nää sisältöön liittyvät kysymykset, ne ei musta siis tohon neuvottelukuntaan kertakaikkiaan sopinu." PT4

"Mut sitten tätä ministeriöiden välistä, siis tällä tavalla ylemmän tason horisontaaliyhteistyötähän, pyrittiin nimenomaan, tän sektoritutkimuksen neuvottelukunnan, kautta aikaansaamaan [...] työryhmän ehdotushan oli, tai ainakin tarkotus oli, että tämmönen, koottu kehittäminen tapahtuis valtioneuvoston kansliassa, siis pääministerin kansliasta käsin. Taikka kanslian alaisuudessa, sanotaan sillä tavalla mieluummin. Siitä syystä että pääministerin tehtävänä on, valtioneuvoston työjärjestyksen mukaan johtaa valtioneuvoston toimintaa. Ja kun tää sektoritutkimus, siinä mielessä kun työryhmä sen ymmärsi on, yhteiskunnan kehittämisen ja yhteiskuntapoliittisen päätöksenteon, tietotason nostamiseen, ja sitä auttamaan pyrkivää toimintaa. Mutta, tämän. hallitus hylkäs tämän ehdotuksen." PT6

Evolutionäärisesti tulkittuna SETU-jaostoilla, konsortioilla ja ohjelmilla haluttiin siis lisätä muuntelua eli tuoda areenalle erilaisia organisaatioaihioita, joita valinnan ajateltiin sitten suosivan perinteisten sektorilaitosten sijaan. Lisäksi tarkoituksena oli luoda valintaympäristöä, joka osaavasti tilaa sellaista tutkimusta, johon tarvitaan tutkimuslaitosten yhteistä panostusta ja johon yhden tutkimuslaitoksen osaamispohja tai tietovarannot eivät riitä. Valintaympäristön kaikki tekijät eivät kuitenkaan vaikuttaneet samaan suuntaan. Taloudellinen valintapaine lähti viemään kulkua toiseen suuntaan, ei suosimaan 


\section{Poliittinen valintaympäristö}

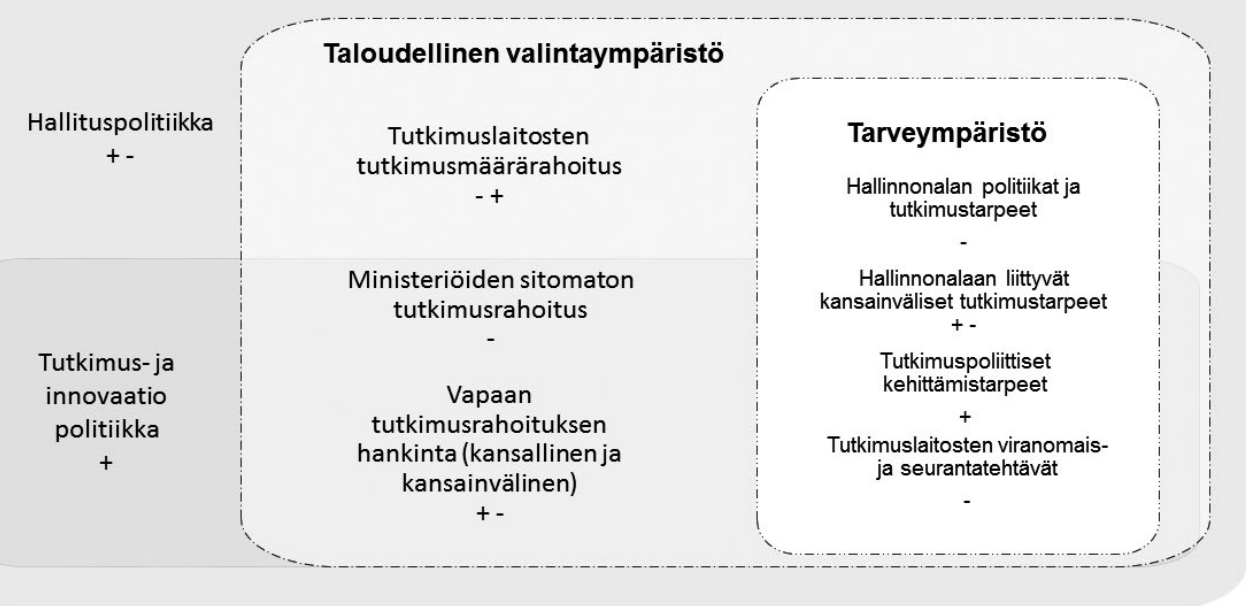

Kuvio 5. Horisontaalisen tutkimuksen edistämisen valintaympäristöt. Esimerkkinä vaikutussuuntien merkityksestä horisontaalitavoitetta suosivat valintaympäristön tekijät on ilmaistu merkillä " + " ja vastustavat merkillä "-" (koottuna informanttien näkemyksistä). Kuvattu tilanne on ennen v. 2013 kokonaisuudistusta.

uusia sopeumia vaan sektoroituneita toimintamalleja (Kuvio 5.). Uutta horisontaalisiin ratkaisuihin kannustanutta resurssia ei ollut riittävästi, vaikka esimerkiksi EU-politiikkojen vaikutuksesta horisontaaliset tietotarpeet lisääntyivät. Jatkuvuuden kannalta sektoritutkimuksen neuvottelukunnasta tehty arviointi oli merkittävä, koska siinä nostettiin aiheita, jotka nousivat uudistamisen kohteeksi seuraavassa vaiheessa eli TULA-uudistuksessa.

Tarkastelujakson viimeisessä vaiheessa itseohjautuvuusmekanismit organisoinnin muotona häviävät laitosfuusiopäätöksille. Tavoitetasollakin tulee muutoksia, kun tutkimustiedon hyödynnettävyyttä korostetaan aikaisempia vaiheita enemmän. Lisäksi tutkimuslaitosten yhteenliittymät tulevat mukaan uutena organisaatiomuotona. Haastatteluaineisto on tämän osalta vajaa, koska uudistuksen lopullisia vaiheita ei ollut haastattelujen aikana vielä nähtävissä. Uudet rahoitusinstrumentit herättivät pohdintaa puolesta ja vastaan. Rahoituksen ohjausjärjestelmien toimivuutta ja niiden kykyä murtaa perinteisiä toimintamalleja epäiltiin. Samoin uudistuksen mielekkyyttä ulottumaan murtamaan koko tutkimusjärjestelmään kyseenalaistettiin, koska joitain sen osia pidettiin aidosti hyvin toimivi- na, kuten perustutkimuksen lohkoa ja Suomen Akatemian riippumatonta roolia. Toisaalta nähtiin muutoksen välttämättömyys etenkin tutkimustiedon hyödynnettävyyden parantamiseksi päätöksenteossa ja kustannustehokkuuden lisäämiseksi tutkimusmäärärahojen vähentyessä.

"Ku sitä sit enemmän penkoo niin, ehkä joku vois sanoo et hyväkin että tää nykynen ehdotus jos sitä lähetään viemään eteenpäin, niin se purkais vähän näitä ongelmia mut, en mä nyt usko, että nekään niitä ydinongelmia ratkasis. Mites tää tulosohjaus nyt jatkossa hoidetaan. Ja kiusaa myös se ettei tuo periaatepäätös silti välttämättä laske niitä hallinnonalan välisiä rajoja." PT3

"[...] ajatus siitä et siellä on tää, konserni, valtiokonsernin näkökulma et tulee se semmoinen strateginen ote ja strateginen paperilinjaus niin se on mun mielestä ihan hyvä. Mut sen vaara on se et kun se mikään ei toimi ilman rahaa ja kun ne rahat kerätään näilt sektoritutkimuslaitoksilta et me luodaan vaan semmoinen byrokraattinen kuvio jossa kerätään rahat ja sit ne jaetaan uudelleen. Niin tää on se riski." YL1 
Evolutionäärisesti tulkittuna TULA-kokonaisuudistus toi murrosvaiheen sekä valintaympäristöihin että toimijakenttään. Poliittinen valintaympäristö ja tarveympäristö haluttiin entistä lähempään vuorovaikutukseen. Tällöin mahdollisuudet eri suuntiin vaikuttaviin voimiin vähenevät. Tarveympäristön rooli valintaa ohjaavana voimana näyttäisi korostuvan ja taloudellinen valintaympäristö entisestään kiristyvän. Verkostoitumisen merkitys vähenee uuden muovaamisessa ja kilpailu evolutiivisena voimana näyttäisi ottavan selkeämpää roolia. Tämä vaikuttaa paitsi tutkimuslaitosten itsenäiseen olemassaoloon myös laitosten sisäiseen organisoitumiseen. Lisäksi tutkimuslaitosten ja korkeakoulujen yhteistyö pyritään nostamaan näkyvämpään rooliin. Uudet rahoitusinstrumentit, jotka sijoittuvat aiemman sektoripohjaisen tarveympäristön ja poliittisen valintaympäristön välimaastoon, voivat tuoda sopeumina uudenlaisia yhteistyömuotoja tuottajakenttään. Jatkuvuutta ylläpitäneet instituutiot kuten valtion tiede- ja innovaationeuvosto uudistettiin ja sektoritutkimuksen koordinaatio siirrettiin valtioneuvoston kansliaan.

Tämän osion otsikossa käytetty valintaympäristön nimi "tutkimuspoliittinen valintaympäristö" on monitasoinen kooste poliittisesta valintaympäristöstä (hallituspolitiikka \& tutkimus- ja innovaatiopolitiikka) ja hallinnonalojen tutkimuspoliittisten tarpeiden tarveympäristöstä. Tämä emergentti valintaympäristö on ollut vähitellen muodostumassa kehitysjaksojen aikana ja on nousemassa esiin lopulta TULAuudistuksen esiintuomana.

\section{Tutkimuksen tilaajaosaamisen, horisontaalitavoitteen ja tutkimus- laitosten yhteistyön toisiinsa limittyvät kehityskulut}

Tarkastelujaksolla voidaan havaita kaksi kehityskulkua, jossa tutkimuspolitiikkataso (osana valintaympäristöä) ja toimijakenttä ovat muuttuneen yhdessä ja vuorovaikutuksessa toisiinsa. Nämä ovat horisontaalisen tutkimuksen tilaajarahoitusmallin ja tilaajaosaamistarpeen muutos sekä horisontaalisen tutkimuksen yhteistyön edistäminen ja yhteistyörakenteet. Itseasiassa nämä kaksi ovat kolmen tason, tutkimuspoliittinen tavoitetaso (poliittinen valintaympäristö), tutkimuspoliittinen keinotaso (tarveympäristö) ja toteuttajataso (ministeriö ja laitostaso), yhteiskulku, jossa prosessi ja konteksti ovat toisiinsa limittyneitä. Seuraavaksi kuvataan tätä kehityskulkua avaamalla aluksi tilaajaosaamiskäsitettä ja sitten konkreettisella esimerkillä luonnonvara- ja ympäristöalalta.

\section{Tilaajaosaaminen}

Yhteiskunnallisesti relevantin tutkimustiedon hankinnan pohjatessa tutkimuksen tilaamisprosessiin on tärkeää huolehtia riittävän laadukkaasta tilaajaosaamisesta. Tämä vaikuttaa sekä tulosohjaukseen että eri rahoitusinstrumenttien ohjaukseen. Tilaajaosaamisen kehittämisen tärkeys mainitaan jo sektoritutkimuksen yleismallin tavoitteissa. Tilaajaosaamisen parantaminen oli listattuna SETU- neuvottelukunnan tehtäviin. Samoin TULA-uudistusta edeltäneen selvitystyön kehittämissuosituksissa se on vielä mukana. Tähän tutkimukseen valitussa prosesseihin kohdistuvassa käytänteiden lähestymistavassa se edustaa tyypillisimmillään prosessin osatekijää. Se on kytkeytyneenä tutkimuksen tilaamisprosessiin ja ilmenee eri toimintatapojen kokonaisuutena.

Tilaajaosaamisen käsite on ollut esillä koko tarkastelujakson ajan niin se, mitä itse asiassa tilaajaosaamisella on eri yhteyksissä tarkoitettu, ei ole ollut yksiselitteistä. Informanteilta kysyttiin, mikä heidän näkökulmastaan on olennaista tilaajaosaamisessa. Tästä rakentui kokonaiskuvaa tilaajaosaamisen käsitteen moniulotteisuudesta. Tilaajaosaamista on tutkimuksen tilauksessa tarvittava hankintaprosessin tai tulosohjauksen hallinta ja varsinainen sisällöllinen osaaminen. Lisäksi tarvitaan kokonaiskäsitystä aiheesta eri hallinnonaloilla sekä kokonaisvaltaisempaa tutkimusosaamista siihen, mitä ylipäätään tutkimuksella voidaan saada ratkaistuksi ja miten tutkimustulokset saadaan päätöksenteon tueksi.

Käytettäessä analyysissa näin muodostunutta tilaajaosaamiskäsitteen kokonaiskuvaa tilaajaosaamistarpeen evoluutio tulee näkyviin. Yleismallin alkuaikoina rahoitustilanne oli helpompi, mutta toiminta tähtäsi enemmän hallinnonalan omaan tarpeeseen. Taloudellisen valintaympäristön kiristyessä ja horisontaalisten tietotarpeiden lisääntyessä katsottiin, että tilaajapuolellekin tarvitaan entistä enemmän horisontaalista 


\section{HORISONTAALITUTKIMUKSEN KEHITTÄMISTAVOITE \\ Politiikkataso}

Horisontaalinen tilaajaosaaminen

Vertikaalinen tilaajaosaaminen

Klusteriohjelma ja

muut yhteisohjelmat

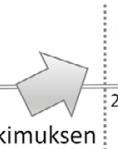

SETU -ohjelmat

konsortiotilauksena

2006

Ympäristötutkimuksen SETU KEKE-jaosto

koordinaatioryhmä -tuottajakonsortio

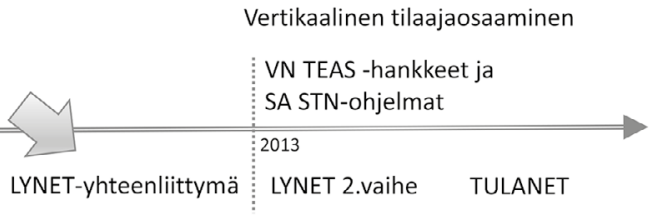

Ministeriö ja tutkimuslaitostaso

YMPÄRISTÖ- JA LUONNONVARA-ALAN RAKENTEELLINEN YHTEISTYÖ

Kuvio 6. Horisontaalisen tutkimuksen kehittämistavoitteen ja ympäristötutkimuksen rakenteellisen yhteistyön rinnakkainen muutoskulku, jossa yhteisevoluutiomaisia piirteitä.

osaamista. SETU-neuvottelukunnan kokemuksista havaittiin, että on järkevää lisätä panostusta tutkimustiedon siirtämiseksi päätöksentekoon. Tämä kuvattu muutos yhdistettynä tilaajaosaamisen kokonaiskuvaan näyttää sen, että tarve on yleistäen muuttunut sektoraalisesta tilaajaosaamisesta horisontaalisuuden kautta vertikaaliseen (tiedon käyttökelpoisuus) tilaajaosaamiseen.

\section{Horisontaalisen tutkimuksen yhteistyörakenteet - esimerkkinä ympäristö- ja luonnonvara-ala}

Ympäristötutkimusta tehdään Suomen ympäristökeskuksen ohella muissakin tutkimuslaitoksissa ja yliopistoissa, joten ympäristötutkimukselle on haettu erilaisia yhteistyömuotoja koko tarkastelujakson ajan. Ympäristöklusterin tutkimusohjelma (Honkasalo 2003, Lemola ym. 2010), oli keskeinen toimija vuosituhannen vaihteessa. Ympäristötutkimuksen koordinaatioryhmä (Taulukko 2.) tehtävänä oli ympäristöministeriön tukena sovittaa yhteen ympäristöhallinnon päätöksentekoa ja ympäristöalan sektoritutkimuksen strategista suunnittelua ja tutkimusresurssien käyttöä sekä kehittää tutkimuksen hyödyntämismekanismeja. Koordinaatioryhmä toimi SETU-neuvottelukunnan aikaan ja osin samoilla osallistujilla SETU:n Kestävä kehitys -jaoston kanssa. Näiden molempien hyvin sujunut sisäinen yhteistyö edisti ympäristötut- kimuksen yhteistyön seuraavaa vaihetta eli yhteenliittymävaihetta.

"Tutkimusorganisaatioiden yhteistyön tehostaminen. Siinä me mun mielestä onnistuttiin melko hyvin, koska kaikkihan lähti kauheen innokkaasti - esimerkiks tää ilmastotutkimusjuttu - aikalailla laittaa omaakin paukkua ja oikein hävettää se et sit..sitä ei jatkettu" PT2

Entistä tiiviimpi ympäristö- ja luonnonvaratutkimuksen toimijoiden yhteistyö alkoi ensin MMM:n alaisten tutkimuslaitosten proLuonnonvarat -aloitteena. Tämä sai vauhtia uhasta hallinnonalan tutkimuslaitoskannan yhdistämiseksi yhdeksi tutkimuslaitokseksi. Ympäristöministeriön tultua mukaan perustettiin Luonnonvara- ja ympäristötutkimuksen yhteenliittymä LYNET. Yhteenliittymällä pyrittiin osoittamaan, että kustannussäästöjä ja yhteisen tutkimustoiminnan tehostamista voidaan saada sopimuspohjaisestikin ilman, että organisaatioita tarvitsee fuusioida. Toiminnan suunniteltiin perustuvan yhteisiin tutkimusohjelmiin sekä tutkimuksen tukipalveluiden ja tutkimuksen infrastruktuurien tehokkaampaan yhteiskäyttöön.

LYNET-yhteenliittymä perustettiin valtioneuvoston asetuksella, joka viittaa siihen, että toimintaa oli tarkoitus viedä pitkäjänteisesti eteenpäin ja yhteenliittymälle pyrittiin hankkimaan organisaatiomaista asemaa. Ministeriöt olivat mukana perustamassa yhteenliittymää ja 
Taulukko 2. Ympäristötutkimuksen tutkimuslaitoskentän merkittävät tapahtumat tarkastelujaksona 1993-2018.

\begin{tabular}{|c|c|c|}
\hline & Vuosi & \\
\hline Suomen ympäristökeskus perustetaan & 1995 & Valtion keskushallinnon uudistus. \\
\hline Ympäristöklusterin tutkimusohjelma & 1997-2009 & $\begin{array}{l}\text { ympäristöministeriön koordinoima, } \\
\text { aluksi osa laajempaa Klusteriohjelmaa, } \\
\text { yhteistyöorientoitunut, muita rahoittajia } \\
\text { TEKES ja Suomen Akatemia. }\end{array}$ \\
\hline Ympäristötutkimuksen koordinointiryhmä & $2006-2009$ & $\begin{array}{l}\text { VN periaatepäätöksella perustettu, } \\
\text { kokoonpanossa eri ministeriöitä, } \\
\text { tutkimuslaitoksia, Suomen Akatemia, } \\
\text { SITRA, yliopistoja. Ympäristöministeriön } \\
\text { kansliapäällikön johtama. }\end{array}$ \\
\hline $\begin{array}{l}\text { Sektoritutkimuksen neuvottelukunnan } \\
\text { Kestävä kehitys-jaosto }\end{array}$ & $2007-2011$ & $\begin{array}{l}\text { SETU neuvottelukunnan yksi jaostoista, jossa } \\
\text { eri ministeriöiden edustajia. Teki ehdotuksia } \\
\text { tutkimusohjelmiksi ja organisoi hankkeita. } \\
\text { Toinen ympäristötutkimusta käsitellyt SETU- } \\
\text { jaosto oli Alue- ja yhdyskuntarakenteet ja } \\
\text { infrastruktuurit -jaosto. }\end{array}$ \\
\hline $\begin{array}{l}\text { Merentutkimuslaitos jaetaan Suomen } \\
\text { ympäristökeskuksen ja Ilmatieteenlaitoksen } \\
\text { kesken }\end{array}$ & 2009 & \\
\hline $\begin{array}{l}\text { Luonnonvara- ja ympäristötutkimuksen } \\
\text { yhteenliittymä LYNET 1.vaihe }\end{array}$ & $2009-2015$ & $\begin{array}{l}\text { MMM ja YM alaisten laitosten yhteenliittymä, } \\
\text { ohjausryhmä kansliapäällikkövetoinen. }\end{array}$ \\
\hline $\begin{array}{l}\text { Luonnonvara- ja ympäristötutkimuksen } \\
\text { yhteenliittymä LYNET 2.vaihe }\end{array}$ & $2015-2017$ & $\begin{array}{l}\text { Laajennettin LVM ja TEM alaisilla laitoksilla } \\
\text { (IL, GTK, VTT), jotka tekevät ympäristö- ja } \\
\text { luonnonvaratutkimusta. Ohjausryhmässä } \\
\text { ministeriöiden kansliapäälliköt } \\
\text { ja johtoryhmässä ministeriöiden } \\
\text { tutkimusjohtajat. }\end{array}$ \\
\hline Luonnonvarakeskus perustetaan & 2015- & MTT, Metla ja RKTL yhdistetään. \\
\hline $\begin{array}{l}\text { LYNET+SOTERKO yhteenliittymät yhdistetään } \\
\text { TULANETiksi }\end{array}$ & 2018 & $\begin{array}{l}\text { Lähes kaikkien sektoritutkimuslaitosten } \\
\text { muodostama sopimuspohjainen rakenne } \\
\text { ilman ministeriöohjausta. }\end{array}$ \\
\hline
\end{tabular}

ohjasivat sen toimintaa ohjausryhmätasolla sekä tulosohjauksen kautta. Toimijakenttään muodostui siis kokonaan uusi organisaatiomuoto, jonka asemaa tuettiin myös ohjaustasolta antamalla sille horisontaalitutkimusta edistävää tehtävää. Samanlainen yhteenliittymä SOTERKO perustettiin sosiaali- ja terveysalalle. Sen sijaan tutkimuspolitiikkatasolle yhteenliittymät eivät välttämättä näyttäytynet riittävän vahvassa roolissa. Nähtiin esimerkiksi näiden yhteenliittymien olleen ns. silmäripsiliikkeitä laitosfuusioita vastaan. Termi tulee painista ja tarkoittaa näennäistä aktiivisuutta.
"[---] tämmösiä painissa tunnettuja silmäripsiliikkeitä, mennään tahallaan alle, jotta aika kuluis eikä vastustaja sais pisteitä enkä minä sais varotuksia. Niin sitte asiat hoituu hyvin. Eli tämmönen, defensiivinen, vaikutelma, on useista näistä, jääny ja tää, LYNET ei ollu tässä suhteessa, mikään poikkeus, vaikka siinä nyt on kysymys, laajemmasta kun vaan, yhden hallinnon alan."

TULA-uudistuksen periaatepäätöksessä MMM:n alaiset tutkimuslaitokset päätettiin yhdistää Luonnonvarakeskukseksi. Yhteenliittymiä ei kuitenkaan lakkautettu vaan vuosina 2015-2017 LYNET:iin kuului seitsemän laitosta ja se oli entistä horisontaalisempi leikaten neljän ministe- 
riön hallinnonalaa (YM, MMM, LVM, TEM). Sittemmin vuonna 2018 LYNET ja SOTERKO yhdistettiin lähes kaikkien valtion tutkimuslaitosten yhteiseksi verkostoksi TULANET:ksi tutkimuslaitosten itsensä aloitteesta. Säädöspohja vaihtui samalla asetuksesta sopimukseksi.

Evolutiivisesti tulkittuna tilaajaosaamistarpeen laajeneminen näyttäytyy politiikka- ja toimijatason yhteisenä muutosilmiönä, joka on samalla ollut vaikuttamassa nykyisten strategisen tutkimuksen rahoitusinstrumenttien muovautumiseen (Kuvio 6.). Valintaympäristöinä näihin molempiin kehityskulkuihin ovat vaikuttaneet tutkimuspoliittiset linjaukset tilaajaosaamisen kehittämisestä, horisontaalitutkimuksen edistämisestä ja sektoritutkimuksen vaikuttavuuden lisäämisestä. Samalla keskeisesti taloudellinen valintaympäristö on tiukentunut.

Kehityskulussa havaittiin yhteisevoluutiomaista vuorovaikutusta niin, että ministeriö-laitostaso ja politiikkataso vaikuttivat toistensa toimintastrategioihin vastavuoroisesti. Uusien strategisten rahoitusinstrumenttien syntyyn johtaneessa kehityksessä ja tilaajaosaamisen tarpeen muutosprosessissa havaitaan vuorovaikutteinen oppimisprosessi, jossa sparrataan toista osapuolta. Ministeriöiden tutkimusosaamisen kehittäminen on mahdollistanut substanssitason yhteistyön syventämisen eri hallinnonalojen välillä. Verrattuna yleismallin alkuaikoihin ministeriöissä on entistä enemmän tutkimusjohtajia ja nimettyjä tutkimusvastaavia. SETUvaiheessa heitä kannustettiin yhteistyöhön jaostoissa, joiden toimivuus sitten osaltaan oli rohkaisuna valtioneuvoston TEAS -toiminnalle TULA-vaiheeseen.

Samalla tavalla yhteenliittymiin liittyvä prosessi on vuorovaikutteinen ja tasot kehittyvät toisiinsa vaikuttaen. Ympäristö- ja luonnonvara-alan tutkimuslaitosten yhteistyön tiivistyminen eteni ympäristöalan koordinointiryhmästä ja rahoitusohjelmasta SETU-vaiheen tilaaja-tuottajamallin jaosten kautta tutkimuslaitosten asetuspohjaiseen yhteenliittymään. LYNET oli evolutiivisesti tulkittuna toimijakentän sopeuma poliittisesta ja tarveympäristöstä tulleille tutkimuspoliittisille fuusiopaineille. Yhteenliittymät toimivat vaihtoehtona tutkimuslaitosten yhdistämiskaavailuja vastaan. Tämä ei lopulta riittänyt vaan LYNETin ensimmäisen vaiheen tutkimuslaitoksista suurin osa fuusioitiin Luonnonvarakeskukseksi. Kuitenkin uusi organisaatiomuoto jäi toimimaan. TULA -vaiheessa yhteenliittymät hyväksyttiin legitiimeiksi toimijoiksi myös tutkimuspoliittiselta tasolta, ne laajennettiin useammalle hallinnonalalle ja niille annettiin tehtävää.

\section{TULOSTEN TARKASTELU}

Yksi tutkimuspolitiikan päätavoitteista on ollut hallinnonalojen rajat ylittävän yhteistyön edistäminen (ks. myös esim. Hyytinen ym. 2009; Kuitunen \& Lähteenmäki-Smith 2006). Tämä myös yleisemmin hallinnon kehittämistä leimannut horisontaalisuuden tavoite (Virtanen 2016) on ollut haaste sektoroituneelle tutkimusjärjestelmälle sekä sisällöllisesti että rakenteellisesti (Lemola 2002; Hyytinen ym. 2009; Lehenkari 2016). Tutkimus- ja innovaatiojärjestelmä vuonna 2019 on erinäköinen kuin vuonna 1990. Rakenne on nykyään yhtäältä monimuotoisempi toisaalta yksinkertaisempi (vrt. Halme ym. $2017,4)$. Tässä käytetty evolutionäärinen tarkastelu osoittaa miten nykyhetkeen on tultu sektoritutkimuksen osalta ja sen perusolettamuksiin kuuluu, että muutosprosessi on emergentti ei niinkään suoraa seurausta erilaisten toimijoiden toimista (Sotarauta 2004, 293).

Evolutiivisten prosessien etenemismekanismit ovat keskeisiä prosessien toiminnan ja niiden ymmärtämisen kannalta (Abatecola 2014, 435; Sotarauta 2004; Van den Ven \& Poole 1995). Rutiinit on usein rinnastettu organisatorisen evoluution replikanteiksi (Breslin 2014; Abatecola 2014, 435). Tämän tarkastelujakson aikana nousee esiin kaksi rutiineihin - vakiintuneisiin tapoihin - liittyvää tekijää, jotka ovat olleet erityisen keskeisiä: polkuriippuvuus ja avaintoimijat.

Ministeriöiden sisäisiin rakenteisiin yltävä sektoroituminen on väljästi tulkittuna polkuriippuvuutta, ilmiöön jossa aiemmat päätökset ja valinnat vaikuttavat seuraaviin valintamahdollisuuksiin (Pierson 2000). Aluksi rakenteellista kehittämistä pyrittiin tekemään systeemin rakenteen sisällä ja huomioiden pitkäaikaiset päätavoitteet rakenteellisen uudistamiseen. Lopulta TULA-mallissa päädyttiin ratkaisuun, jossa perusrakenteet katsottiin uudestaan systeemiä kokonaisuudistaen ja näin polkuriippuvuuksia ikään kuin katkaistiin. Tutkimuksen 
tilaajaosaamisen rooli näyttäytyy sekä toisaalta ruokkimassa sektoroitumista, mutta myös evolutiivisen prosessin osana, rutiinina, joka muuttuessaan vaikuttaa toiminnan ilmiasuun (Breslin 2014). Avaintoimijoita ovat erityisesti tutkimus- ja innonvaationeuvoston ja SETU-neuvottelukunnan sihteeristöt sekä selvitysmiehet. Heidän roolinsa nousee esiin, kun katsotaan kehittämisen hallintaa. TIN- raportit ovat olleet suunnittelijoiden työkalu ja he ovat voineet nostaa sinne hallinnon ajankohtaisia trendejä. Selvitysmiehet ovat tehneet kattavia yhteenvetoja ja suosituksia omia taustojaan heijastaen. TIN:n suunnittelijat ovat toimineet myös selvitysmiesten taustaryhmissä. He ovat toimineet governance-tyyliin nostamalla esiin ratkaisumalleja, kuten alun perin systeemisen sektoritutkimuksen yleismallin ja markkinamekanismin sekä yhteistyön ja verkostoitumisen työkaluina horisontaalisen tutkimuksen edistämisessä. He ovat pitäneet esillä sektoritutkimuksen keskeisiä haasteita ja tutkimusjärjestelmän rakenteellisen kehittämisen tavoitteita kehityskulun eri vaiheissa ja tuoneet kokemuksia edellisistä vaiheista seuraaviin kehittämislinjauksiin ja -suunnitelmiin. Näin he ovat mahdollistaneet jatkuvuutta ja tavoitteiden säilyttämistä.

Julkishallinnon arviointikäytännöt näyttävät tarkoituksenmukaisuutensa. Arvioinnit toimivat organisaatiorakenteen seuraavan sukupolven käynnistäjänä. Tarkastelujakson aikana erityisesti kaksi arviointia nousevat esiin käännekohtina. Toinen on vuosituhannen vaihteessa tehty sektoritutkimuslaitosten arviointi ja siitä tehdyt johtopäätökset horisontaalisen tutkimuksen lisäämistarpeesta (Karjalainen 2005). Toinen merkittävä arviointi on Sektoritutkimuksen neuvottelukunnan arviointi (Harrinvirta 2010). SETU-ajanjaksolla on ollut selkeä merkittävyytensä kehittämismahdollisuuksien tarkentajana (tilaaja-tuottajamallin kokeilu, hallinnonalojen tutkimusyhteistyön ja tilaaja-tuottajaverkostoitumisen mahdollisuudet ja rajoitteet). SETUneuvottelukunnasta saadut kokemukset huomioitiin ehdotuksessa tutkimuslaitosten ja tutkimusrahoituksen kokonaisuudistukseksi.

Eri valintaympäristötekijöiden vaikutussuuntien merkitys riittävän valintapaineen muodostumisessa on keskeistä. Rakenteellisen kehittämisen keinoissa nojattiin tutkimusjärjestelmän sisäisen dynamiikan kautta tapahtuvaan itseuudistumiseen (markkinamekanismin tai yhteistyöverkostoitumisen kautta). Inertiaa eli muutoshitautta kehityskulkuun toivat toimintaympäristön valintapaineiden vastakkaiset voimasuunnat. Nämä ympäristötekijät ovat joko kumonneet toistensa vaikutuksen tai muutos on tullut ilmi eri tavalla mihin alun perin on pyritty. YLEIS-vaiheessa erityisesti hallinnon yleisen kehittämisen ja tutkimuspolitiikan tavoitteiden edistämiskeinot olivat ristiriidassa. Tulosohjaus osoittautui tutkimusmarkkinaehtoista rakenteellista kehittämistä jarruttavaksi voimaksi. SETU-aikaan ristiriita oli tarveympäristön ja taloudellisen ympäristön välillä. Horisontaalisille tutkimustarpeille ei löytynyt riittävästi lisärahoitusta etenkään vuoden 2008 rahoituskriisin jälkeen. TULA-vaiheen arvioinnissa havaittiin samaa ilmiötä seuraavassakin vaiheessa (Haila ym. 2017). Inertiaa aiheuttivat myös koetut hankaluudet muutoksen hallinnassa. YLEIS-mallissa itseuudistumiseen kannustaminen ei onnistunut vaikkakin tutkimuksen lisärahoitusohjelma oli tarjolla lisäresurssina. Vieläkin selkeämmin hallinnan haasteita kohdattiin SETU-vaiheessa, jossa horisontaalisten yhteistyöverkostojen hallintaan yli sektorirajojen ei oltu valmiita. Yhdessä nämä havainnot muutoskitkan syistä osoittavat tutkimuspolitiikan tavoiteasetannan ja keinovalikoiman voimattomuutta yhtäältä suhteessa hallituspolitiikkaan ja toisaalta suhteessa hallinnon sektoreihin. Tutkimus- ja innovaationeuvoston arvioinnissa (Pelkonen 2014) havainnot ovat samansuuntaisia ja siellä suositellaankin toimenpiteitä neuvoston toiminnan kehittämiseksi ja vahvistamiseksi.

Evolutiivisesti tulkittuna TULA-uudistuksen uudet rahoituskanavat kehittyivät tilaajaosaamisen-tilaajamallin-yhteistyörakenteen vuorovaikutteisessa prosessissa. Samassa useamman tason yhteisevoluutioprosessissa muodostuivat ja muokkaantuivat myös tutkimuslaitosten yhteenliittymät. Ministeriö-laitostaso ja politiikkataso vaikuttivat toistensa toimintastrategioihin vastavuoroisesti ja lisäksi oli hallitsemattomia ympäristötekijöitä. Yhteisevoluution (co-evolution esim. Sotarauta 2004,305; Porter 2006) käsite on myös alkuaan peräisin biologiasta ja sitä yhä laajemmassa määrin sovelletaan organisaatiotutkimuksissa (Abatecola 2014, Christensen 2007, Lewin \& Volberda 1999, Mytelka \& Smith 2002, Sotarauta \& Kautonen 
2007). Yhteisevoluutiossa muutosta tapahtuu yhtäaikaisesti prosessin ja kontekstin vuorovaikutuksessa. Kyse on toisiinsa kietoutuneista prosesseista, jotka voivat tapahtua samalla tai eri tasoilla.

Organisaatioiden evoluutiotutkimusta yhteen vetävässä artikkelissaan Abatecola (2014, 441) näkee yhteisevoluutiotutkimuksen lupaavimpana evolutiivisen organisaatiotutkimuksen alana, koska se yhdistää determinististisen ja voluntaristisen ontologian ympäristön vaikutuksesta (myös Hodgson 2013). Tässä tutkimuksessa lähdettiin liikkeelle organisaation ja ympäristön välisestä vuorovaikutuksesta, mutta aineistosta nousseiden havaintojen perusteella lähestymiskulma laajeni myös yhteisevolutiiviseen tarkasteluun. Tämä puolestaan nosti esiin monitasoisen vuorovaikutteisen muutosdynamiikan. Havainnot tässä kohtaa ikään kuin osoittivat teoriataustaansa. Tutkimuksen viitekehystä määriteltäessä vaihtoehtona oli myös olio-pohjainen tarkastelu, jossa tarkasteltavat yksiköt olisivat olleet itse organisaatiot ei mekanismit tai toimintatavat (Breslin 2014). Tämän mielekkyys oli kuitenkin epävarmaa, koska laajemmassa viitekehyksessä tarkasteltavana oli sektoritutkimusjärjestelmä yhtenä kokonaisuutena ja toisaalta laitosten määrä tässä tarkastelussa on suhteellisen pieni. Evolutionäärisen lähestymistavan mahdollisti aineiston kattama pitkä ajanjakso, jolloin muutosta, mekanismeja ja avaintoimintoja pystyi tunnistamaan. Tarkastelujakson systemointi kolmeen ajanjaksoon, ikään kuin sukupolveen, teki analyysista hallittavamman. Sen sijaan valintaympäristön rooli ei ollut kaikissa tapauksissa yksiselitteistä. Koko aineiston tarkastelu yhteisevoluutioprosessina olisi voinut myös olla mahdollista ja mahdollisesti selkeyttänyt valintaympäristöjen tahdonalaisuuksien loogisuutta. Tähän valittu valintaympäristömääritelmä ja -jako toivat kuitenkin esiin ympäristön dynamiikkaa ja puolustavat siksi paikkaansa.

\section{JOHTOPÄÄTÖKSET}

Evoluutio muokkaa organisaatiot soveltuviksi ympäristöönsä. Tämän tutkimuksen evolutionäärisen viitekehyksen mukaisesti ympäristön muuttuessa myös organisaatiot muuttuvat. Ympäristöön vaikuttamalla voidaan epäsuorasti vaikuttaa myös organisaatioon. Näin tulkittuna tässä tutkimuksessa tarkasteltu sektoritutkimuksen rakenteellinen kehittäminen näyttäytyy vaikutus- ja oppimisprosessina, jossa tutkimuslaitoksia ohjataan kohti tavoiteltua rakennetta pyrkimällä muokkaamaan niiden ympäristöä. Keinovalikoima heijastaa sen hetkisiä julkishallinnon suuntauksia ja aiempien ajanjaksojen kokemuksia. Tavoitteena oli revoluution sijasta evoluutio. Ihan loppuun asti tässä tavoitteessa ei päästy vaan viimeisimpänä toteutettu tutkimuslaitosten ja -rahoituksen kokonaisuudistus ulottuu sekä järjestelmään että ympäristöön.

Sektoritutkimuslaitosrakenteen uudistamisessa ollaan pääsemässä tavoiteltuun rakenteeseen eli muutamaan suureen ja yhteiskunnallisesti tarkoituksenmukaiseen yleistutkimuslaitokseen. Sektoritutkimuksen rakenteellinen uudistaminen ja sen hallinta olivat haasteellisempaa kuin alun perin odotettiin. Omaehtoinen itseuudistuminen uusien yhteistyömallien avulla jäi pitkälti tavoitteeksi riittävän valintapaineen puuttuessa. Uudistamistoimien nopeampi vaikuttavuus olisi vaatinut toimijatasojen ja toimintaympäristön eri muutossuuntien voimakkaampaa synkroniaa eli vahvempaa tutkimuspoliittista otetta. Tutkimuslaitosten ja -rahoituksen kokonaisuudistus rikkoi sittemmin polkuriippuvuuksia ja aloitti uuden aikakauden uusine rahoitusmalleineen. Pohdittaessa valittujen uudistamistoimien oikeellisuuta voi todeta, että tarvittavan pitkäjänteisiä suoran vaikuttamisen tutkimuspoliittisia mekanismeja ei ole ollut käytettävissä. Ympäristö- ja luonnonvara-alan esimerkit osoittavat avoimien järjestelmien toiminnan hallinnan haasteellisuuden. Eri tason ympäristöjen epäsynkronia tai vastakkaiset vaikutussuunnat voivat johtaa jopa päinvastaisiin tuloksiin kuin tavoitellaan.

Entä tavoite horisontaalisen tutkimuksen ja yhteistyön lisäämiseksi? Sektoritutkimuksen huoli on edelleenkin siiloutuminen. Aika näyttää kuinka vahvasti siiloutuminen siirtyy suurten tutkimuslaitosten sisälle. Tämän tutkimuksen jälkeen tehdyssä TULA-uudistuksen arvioinnissa todetaan, että reformin jälkeenkin strategisen tahtotilan ja toteuttamisen välille jäi kuilu. Tavoitteena oli rikkoa hallinnonalojen välisiä raja-aitoja, mutta toteutus jäi hallinnonaloille osittain "siiloihin" (Haila ym. 2018). Arvioinnin johtopäätöksissä esitetään, että verkos- 
tomaisten yhteistyörakenteiden tulisi jäädä pysyväksi käytännöksi. Verkostorakenteet näyttäisivät kuitenkin tämän tutkimuksen valossa häviävän fuusiolaitosrakenteelle. Havainnot osoittavat, että käytännön tasolla helposti mennään tilanteeseen, jossa oman hallinnonalan etujen turvaaminen on ensisijalla. Toimintamalleja sujuvaan yhdessä resursointiin ja yhteistyön hallintaan ei ollut vielä valmiina. Epäilemättä yhteistyö eri muodoissaan tulee jatkossakin olemaan keskeistä, joten näitä valmiuksia on kehitettävä edelleen mentäessä kohti ilmiöpohjaista hallintoa. TULA-arvioinnin mukaan yhteistyö eri toimijoiden välillä on ollut sittemmin monipuolista ja yhteisten tietotarpeiden tunnistus on kehittynyt ministeriöissä. Sen sijaan uudistuksen ohjaus ja seuranta on ollut puutteellista,

\section{LÄHTEET}

Abatecola, Gianpaulo (2014). Research in organizational evolution. What comes next? European Management Journal 32, 434-443.

Aldrich, Howard, E. (2007). Organizations and Environments. Standford Business Classiscs. Standford University Press.

Aldrich, Howard E. \& Ruef, Martin (2006). Organizations Evolving. SAGE Publications Ltd. Haettu sivulta https://amirone2006.files.wordpress.com/2014/02/aldrich-and-ruef-2006.pdf, 19.6.2019.

Baum, Joel, A. C. \& Shipilov, Andrew V. (2006). Ecological Approaches to Organizations. Sage Handbook for Organization Studies, sivut 55110.

Breslin, Dermont (2008). A review of the evolutionary approach to the study of entrepreneurship. International Journal of Managemewnt Reviews. Haettu sivulta https://doi.org/10.1111/ j.1468-2370.2008.00234.x, 17.6.2019

Breslin, Dermont (2014). What evolves in Organizational Co-Evolution? Journal of Management \& Governance, vol. 20(1), sivut 45-67.

Cairney, Paul (2013). What is evolutionary theory and how does it inform policy studies. Policy \& Politics 41, 279-298.

Christensen, Tom, Lagreid, Per, Roness, Paul G. \& Rövik, Kjell Arne (2007). Organization Theory and the Public Sector - Instrument Culture and Myth. Taylor \&Francis Group. London.

Eela, Riikka (2001). Suomen teknologiapolitiikka valtion tiede- ja teknologianeuvoston katsa- sillä millään taholla ei ollut strategista kokonaiskuvaa ja uudistuksen vetovastuuta. (Haila ym. 2018). Sektoritutkimusta kokonaisuutena kehittävälle politiikalle yhden mahdollisuuden tarjoaa uudistettu asetus Valtion tutkimus- ja innovaationeuvostosta sekä neuvostolle annettujen tehtävien, kokoonpanon kuin yhteen sovittavan toimintamuodonkin kautta.

\section{KIITOKSET}

Kiitän kahta vertaisarvioijaa käsikirjoituksen kommentoinneista ja hyvistä parannusehdotuksista. Aineiston hankintaan on saatu tukea ESRhankkeelta VERKA (Verkostoista allianssiksi) S11458.

usten valossa. Työpapereita nro 56/01, VTT. Haettu sivulta http://www.vtt.fi/inf/julkaisut/ muut/2001/tp56.pdf, 19.6.2019.

Haila, Katri, Hjelt, Mari \& Pulkkinen, Kirsi (2017). Välttämätön ja hyvä uudistus, jolta vedettiin matto alta. Tieto käyttöön blogi. Haettu sivulta http://tietokayttoon.fi/ajankohtaista/blogi/-/ blogs/valttamaton-ja-hyva-uudistus-jolta-vedettiin-matto-alta, 19.9.2017.

Haila, Katri, Aarrevaara, Timo, Hjelt, Mari, Paavola, Heli, Palomäki, Santeri, Pulkkinen, Kirsi, Raivio, Tuomas, Rannikko, Heikki, Sepponen, Susanna \& Valtakari, Mikko (2018). Valtion tutkimuslaitosten ja -rahoituksen kokonaisuudistuksen (TULA-uudistuksen) arviointi. Valtioneuvoston selvitys- ja tutkimustoiminnan julkaisusarja $74 / 2018$.

Halme, K., Saarnivaara, V-P. \& Mitchell, J. (2017). RIO Maaraportti 2016: Suomi; EUR 28485 FI. Haettu sivulta: doi:10.2760/023247, 19.6.2019.

Harrinvirta, Markku (2010). Sektoritutkimuksen neuvottelukunnan ja jaostojen arviointi. Loppuraportti. Sektoritutkimuksen neuvottelukunta $7 / 2010$.

Honkasalo, Antero (2003). Ympäristöklusterin tutkimusohjelma. Suomen ympäristö 652. Suomen ympäristökeskus. Edita Prima Oy.

Hodgson, Geoffrey M. (2013). Understanding Organizational Evolution: Toward a Research Agenda using Generalized Darwinism. Organization Studies 34(7), 973-992.

Huttunen, Jussi (2004). Valtion sektoritutkimusjärjestelmän rakenteellinen ja toiminnallinen ke- 
hittäminen. Selvitysmiesraportti. Haettu sivulta http://ktm.elinar.fi/ktm_jur/ktmjur.nsf/0/ a831f3bfeb44ad2dc2256f090024f58d/\$FILE/ Jussi_Huttunen_2004.pdf, 19.6.2019.

Hyytinen, Kirsi \& Loikkanen, Torsti \& Konttinen, Jari \& Nieminen, Mika (2009). Valtion tutkimuslaitosten muutokset ja muutosten haasteet. Sektoritutkimuksen neuvottelukunta 3/2009.

Jalonen, Harri (2006). Kompleksisuusajattelu yhteiskuntatieteissä. Politiikka 48:2, 115-126.

Kallio, O. (1995): Ympäristön vaikutus kuntaorganisaation toimintaan. Acta Universitas Tamperensis. Tampere.

Karjalainen, Sakari (2005). Julkisen tutkimusjärjestelmän rakenteellinen kehittäminen. Opetusministeriö. Muistio. 1.4.2005.

Kay, Adrian \& Baines, Darrin (2017). Evolutionary approaches to the concept of drift in policy studies, Critical Policy Studies 13:2, 174-189.

Kokko, Hanna (2009). Mitä jokaisen tulisi tietää evoluutiosta? Teoksessa: Hanski, Ilkka, Niiniluoto, Ilkka \& Hetemäki, Ilari (toim.), Kaikki evoluutiosta (s. 22-23). Tieteellisten seurain valtuuskunta. Gaudeamus.

Kuhmonen, Tuomas (2014). Maaseudun liiketoiminnan uudistuminen. Evolutionäärinen viitekehys. Tulevaisuuden tutkimuskeskus. Tutu e-julkaisuja 17/2014 Haettu sivulta http://docplayer. fi/20527051-Tuomas-kuhmonen-evolutionaarinen-viitekehys.htm, 19.6.2019

Kuitunen, Soile \& Lähteenmäki-Smith, Kaisa (2006). Horisontaalistumisen paineessa? Teknologia- ja innovaatiopäätöksenteon hallinta Suomessa. Hallinnon tutkimus, 3, 16-29.

Lehenkari, Janne, Pelkonen, Antti, Nieminen, Mika, Loikkanen, Torsti, Arnold, Erik \& Luukkonen, Terttu (2016). Osaamispääoman hyödyntäminen ja vaikuttavampi julkisten T\&K voimavarojen kohdentaminen Valtioneuvoston selvitys-ja tutkimustoiminnan julkaisusarja 60/2016 Haettu sivulta http://tietokayttoon.fi/documents/ 10616/334527/Osaamisp\%C3\%A4\%C3\% A4oman+hy\%C3\%B6dynt \%C3\%A4minen+ja/ c8851269-4f9f-41e3-85f1-0a141a913552? version $=1.0,19.6 .2019$.

Lemola, Tarmo (2002). Convergence of national science and technology policies: the case of Finland. Research Policy 31(8-9), 148-149.

Lemola, Tarmo, Hukkinen, Janne, Kuisma, Mika, Viljamaa, Kimmo \& Lahtinen, Henri (2010). Ympäristöklusterin tutkimusohjelman loppuarviointi. Ympäristöministeriön raportteja 8/2010. Ympäristöministeriö. Edita Prima Oy. Helsinki.

Lewin, Arie Y., Long, Chris P. \& Carroll, Timothy N. (1999). The coevolution of new organiza- tional forms. Organizational Science, 10(5), 535-550.

Lewin, Arie Y. \& Volberda, Henk W. (1999). Prolegomena on coevolution: A framework for research on strategy and new organizational forms. Organization Science, 10(5), 519-534.

Lewis, Orion A. \& Steinmo, Sven (2012). How Institutions Evolve: Evolutionary theory and Institutional change. Polity, 2012, 44:3, 314-339 Mytelka, Lynn K. \& Smith, Keith (2002). Policy learning and innovation theory: an interactive and co-evolving process. Research Policy, 31, 1467-1479.

Nelson, Richard R., Dosi, Giovanni, Helfat, Constance E., Pyka, Andreas, Saviotti Pier Paolo, Lee Keun, Dopfer, Kurt, Malerba, Franco \& Winter, Sidney G. (2018). Modern Evolutionary Economics. An overview. University Printing House, Cambridge, United Kingdom.

Pelkonen, Antti, Nieminen, Mika \& Lehenkari, Janne (2014). Tutkimus- ja innovaationeuvoston toiminnan ja vaikuttavuuden arviointi. Opetus- ja kulttuuriministeriön julkaisuja 2014:6. Opetus- ja kulttuuriministeriö. Helsinki.

Pierson, Paul (2000). Increasing returns, path dependence and the study of politics. American Political Science Review 94:251-256.

Porter, Terry B. (2006). Coevolution as a research framework for organizations and the natural environment. Organization \& Environment 19(4), 479-504. Haettu sivulta http://oae.sagepub.com/content/19/4/479.full.pdf + html, 19.6.2019.

Rantanen, Jorma (2008). Sektoritutkimuksen selvitysraportti. Sektoritutkimuksen neuvottelukunta 1/2008. Haettu sivulta http://www.hare.vn.fi/ upload/Julkaisut/13135/3802_setu_1-2008.pdf, 19.6.2019.

Saaranen-Kauppinen, Anita \& Puusniekka, Anna. (2006). KvaliMOTV - Menetelmäopetuksen tietovaranto [verkkojulkaisu]. Tampere: Yhteiskuntatieteellinen tietoarkisto. Haettu sivulta: https://www.fsd.uta.fi/menetelmaopetus/, 15.10.2019.

Sektoritutkimuksen neuvottelukunta (2011). Katsaus sektoritutkimuksen neuvottelukunnan toimintaan 2007-2011. Haettu sivulta http:// docplayer.fi/31784809-Katsaus-sektoritutkimuksen-neuvottelukunnan-toimintaan.html, 19.6.2019.

Sektoritutkimustyöryhmä (2006). Sektoritutkimustyöryhmän mietintö. Valtioneuvoston kanslian julkaisusarja 21/2006. Haettu sivulta https:// www.edilex.fi/ministerioiden_julkaisut/4243, 19.6.2019. 
Sotarauta, Markku (2004). Muutoksen viides ulottuvuus: Evolutionäärinen tutkimusote ja yhteisevoluutio aluekehityksen tutkimuksessa. Teoksessa Sotarauta, M. \& Kosonen, K-J. (toim.) Yksilö, kulttuuri, innovaatioympäristö. Avauksia aluekehityksen näkymättömään dynamiikkaan, (s. 283-317). Tampere: Tampere University Press. Haettu sivulta http://urn.fi/ URN:ISBN:951-44-6124-x, 19.6.2019.

Sotarauta, Markku \& Kautonen, Mika (2007). Coevolution of the Finnish national and local innovation and Science arenas: Towards a dynamic understanding of multi-level governance. Regional Studies, 41(8), 1085-1098. Haettu sivulta https://www.tandfonline.com/doi/ abs/10.1080/00343400701292284, 19.6.2019.

Valtion tiede- ja teknologianeuvosto (1993). Tiedon ja osaamisen Suomi - Kehittämisstrategia. Painatuskeskus, Helsinki.
Valtioneuvoston kanslia (2012). Valtion tutkimuslaitokset ja tutkimusrahoitus: esitys kokonaisuudistukseksi. Valtioneuvoston kanslian julkaisusarja 3/2012. Haettu sivulta http://vnk.fi/ documents/10616/336900/Valtion+tutkimus laitokset+ja+ tutkimusrahoitus_esitys+kokonaisuudistukseksi. pdf/de41c 5ae-e160-47d2a219-4df2bc45286e/ Valtion+ tutkimuslaitokset+ja+ tutkimusrahoitus_esitys+kokonaisuudistukseksi.pdf, 19.6.2019.

Virtanen, Turo (2016). Finland, active reformer looking for more centralisation and horizontal coordination. Teoksessa Hammerschmid, Gerhard, Andrews, Rhys, Bezes, Philippe, Van de Walle, Steven (toim.) Public Administration Reforms in Europe: The View from the Top (s. 129-139). Edward Elgar Publishing. Cheltenham, UK. eBook. ISBN 9781783475407. 